\title{
La reforma beneficial en la colegiata de Zafra
}

\author{
José Sarmiento Pérez
}

\section{RESUMEN}

Por el deseo del entonces virrey de

Sicilia D. Lorenzo Suárez de

Figueroa y de su hijo D. Gómez se erigió la Colegiata de Zafra mediante

la Bula del Papa Paulo V de 10 de diciembre de 1609 y confirmada por decreto de 12 de diciembre de 1612.

Después de varios pleitos de jurisdicción entre el obispo y la nueva Colegial, Felipe IV permitió la

creación de esta entidad, que confirmó el Papa Urbano VIII con su

Bula de Concordia expedida en Roma el 13 de enero de 1631 y que el Rey aprobó por Real Cédula de 18 de octubre de 1633. La Colegiata de Santa Maria de Candelaria fue objeto de varios planes beneficiales que se vieron influenciados negativamente por los problemas de jurisdicción latentes desde su misma creación. En principio el obispo

Pérez Minayo elaboró el de 1770 , que no llegó a verificarse, a éste le siguieron el de Solis y Gragera, el de 1796 y el de Mateo Delgado Moreno

de 1816, que corrieron la misma suerte. El primer paso dado en firme para la supresión de la Colegiata se dio con el arreglo provisional de 11

de junio de 1836 del entonces gobernador eclesiástico Blázquez Prieto. Este proceso culminó con el Concordato de 1851, por el que de nuevo la Colegiata paso a adquirir

\section{SUMMARY}

The Colegiata de Zafra was constructed on the request of then Viceroy of Sicily don Lorenzo Suarez de Figueroa and his son don Gómez, approved by a bull issued by Pope Paul $V$ on the 10th of December 1609, and confirmed by decree on the 12th of December 1612. After various lawsuits between the bishop and the new mother superior concerning jurisdiction, Felipe IV allowed the creation of this entity, which was confirmed by Pope Urban VIII in the bull of Concordia issued in Rome on the 13th of January 1631, and approved by royal mandate on the 18th of October 1633. The Colegiata de Santa Maria de Candelaria was the object of several beneficial plans that were negatively influenced by the problems of jurisdiction existing since its foundation. The first of these was the plan of 1770 , created by bishop Pérez Minayo, never realized; this was followed by Solis y Gragera's plan in 1796 and Mateo Delgado Moreno's plan in 1816, all of which met the same fate. The first step toward the dissolution of the Colegiata was taken by the then Ecclesiastic Governor Blázquez Prieto in the provisional arrangement of June 11th 1836. This process culminated in the Concordat of 1851 
su antigua condición de parroquia, después de 242 años de existencia

Palabras claves: Colegiata, beneficios, jurisdicción, Concordato by which the Colegiata once again acquired its former condition of parish, after 242 years of existence Keywords: Colegiata, Benefit,

\section{ESTADO DE LA CUESTIÓN}

Los estudios dedicados a la iglesia Colegial de Zafra son muy escasos. Cronológicamente la primera referencia bibliográfica sobre esta entidad eclesiástica la ofreció el presbítero Manuel Vivas Tabero, con su libro ya clásico titulado Glorias de Zafra o recuerdos de mi patria, publicado en Madrid en 1901. No fue hasta el año 1982 cuando Marcelino Cardalliaguet Quirant publicó un artículo de tipo económico sobre la Colegiata en la Revista de Estudios Extremeños bajo el título «Las rentas de la insigne iglesia Colegial de Zafra (Badajoz) a finales del Antiguo Régimen». Sin embargo, la obra más completa y mejor documentada ha sido realizada por Francisco de Croche Acuña, cronista oficial de Zafra, titulada La Colegiata de Zafra (1609-1851). Crónica de luces y sombras, publicada en Zafra en 1984 y en el que se narra todos los avatares históricos sufridos por esta entidad hasta que de nuevo pasó definitivamente a la categoría de parroquia mediante el Concordato de 1851. Del mismo autor ha aparecido recientemente publicado -en 1998- también en esta misma localidad un pequeño libro Crónicas de cabildos. Gacetillas o noticias cortas extraídas de actas de las instituciones capitulares de Zafra, consistente en la exhumación de multitud de notas breves y apuntes sueltos, narrados cronológicamente desde el siglo XVII y extraídos de documentos y antiguos legajos existentes en los libros de actas del Cabildo de la Colegiata de la Candelaria, en el Archivo Histórico Municipal, en el Archivo de Feria y en los Protocolos Notariales de la villa de Zafra.

En cuanto a las fuentes inéditas utilizadas, y al ser el objetivo del presente artículo la Reforma Beneficial, he consultado en principio el Archivo del Arzobispado de Mérida-Badajoz (AAMB), centrando la atención en dos secciones. En la de Zafra, consultando los legajos: 89 (números $3.141,3.151,3.154$ y 3.158) y 90 (número 1.361). Y en la de Badajoz: Mitra (legajo 13), Actas de Santa Visita (legajo 15), Curia (legajo 3) y Decimal (legajo 1). He completado mi estudio en el Archivo Histórico Nacional (AHN) en la sección denominada Consejos Suprimidos, expedientes abultados, legajos: $15.595,15.596$ y 15.597. 


\section{ANTECEDENTES HISTÓRICOS DE LA COLEGIATA DE ZAFRA}

En el año 1609 Zafra era una de las villas más populosas del Estado de Feria, en dicha población no había más que una sola parroquia dedicada a Santa María de Candelaria, y servida por un cura, llamado Prior, dos beneficiados y ocho capellanes, dotados los primeros con medio noveno de la masa decimal, no constando que los últimos tuviesen otra asignación que las obvenciones de la parroquia. Pero el entonces virrey de Sicilia D. Lorenzo Suárez de Figueroa y su hijo D. Gómez decidieron aumentar el culto a Dios, para lo que fueron a Roma y manifestaron al Sumo Pontífice que el pueblo de Zafra, del obispado de Badajoz, cabeza de todos sus numerosos estados, era merecedor de que en él se fundase una Colegiata ${ }^{1}$.

El Papa Paulo $V$ accedió a dicha petición y promulgó la Bula de Erección de la Colegiata el 10 de diciembre de 1609, comisionando a D. Anto-

1 El Excmo. Sr. D. Gómez Suárez de Figueroa para la consecución de dicho objetivo expuso: "Que en la villa de Zafra del obispado de Badajoz era célebre entre los pueblos comarcanos, y de los más principales de ellos. Cabeza del Ducado de Feria con un territorio amplio y feraz, abundante de las cosas necesarias a la vida humana, con más de 1000 casas o familias habitadas por hombres doctos, nobles y eclesiásticos constituidos en los sagrados órdnes, con otras personas de honesta condición, pero que en ella no habia una iglesia Colegial, en la que diaria y colegialmente se celebrasen las misas solemnes, horas canónicas y demás divinos oficios, tanto matutinos como vespertinos, sino tan solamente una iglesia parroquial o prioral bajo la advocación de Santa Maria Candelaria, insigne por la magnificencia y hermosura de su construcción, la qual estaba surtida abundantemente de todo lo conveniente al estado de una iglesia Colegial. Que en ella había un curato cuyas rentas, frutos y productos no pasaban de 200 ducados de oro de Cámara; dos beneficios simples perpetuos de valor de 100 ducados de la misma moneda; tres capellanias o legados piadosos, el uno fundado por Martín Fernández Corrales, y los otros dos por Fernando Jaramillo con 570 ducados igualmente de oro de Cámara, diferentes rentas anuales, piadosas memorias o capellanías, con la renta de1.600 ducados de dicha moneda establecidas por algunos fieles cristianos, y principalmente por los Condes de Feria y sus mujeres D." Margarita de Arintón, Juana Dormer, su abuela paterna, e Isabel de Mendoza su madre, de que se hallaba administrador y patrono, con otras rentas o censos perpetuos que en cantidad de 100 ducados de vellón anuales dexó Pedro Hernández de Gerez para casar algunas huérfanas de su linage, cuyas rentas se aplicasen a una mesa capitular, instituyéndose la iglesia Colegial en el competente número de dignidades, canonicatos, raciones y capellanias perpetuas, se probeería considerablemente al feliz estado de la iglesia, al acercamiento del culto divino, al mayor lustre de la villa de Zafra, consuelo espiritual de su clero y pueblo y salvación de las almas, sin que por esto quedasen defraudadas las últimas voluntades de los fundadores y que sobre las rentas ya especificadas, ya fundadas, daria perpetuamente de sus propios bienes a la expresada Mesa para aumento de sus rentas la cantidad de 500 ducados de vellón; mediante lo qual suplicaba a su Santidad se sirviese erigir en Colegiata la iglesia parroquial de la villa de Zafra, proveyendo lo conveniente en su razón". Reglamento de la Iglesia Colegial y parroquial de la villa de Zafra, AAMB, Zafra, leg. 90, n. ${ }^{8} 3.161$, f. 120. 
nio Caciano, Nuncio en Madrid y Arzobispo de Capua, para que justificadas las preces presentadas por el nuevo Duque de Feria D. Gómez Suárez de Figueroa, pasase a hacer la unión de beneficios y su aplicación a la mesa capitular. Examinados los documentos y después de recibir la información de testigos el Nuncio dio su decreto final el 12 de diciembre de 1612, declarando erigida por tanto la iglesia parroquial en Colegial, con un abad mitrado, arcediano de Feria, chantre, tesorero, magistral, doctoral, diez canónigos, ocho racioneros, ocho capellanes de coro y el competente número de ministros inferiores. Al abad se le concedió el uso de sus vestiduras episcopales y jurisdicción ordinaria omnimoda sobre todos los prebendados, capellanes, ministros y oficiales de la Colegial 2 . Tenía la facultad de nombrar provisor y vicario general, un canónigo para el ejercicio de la "cura animarum" y que éste a su vez nombrase dos coadjutores racioneros, quienes percibirían lo que produjese la administración de los sacramentos. El cura mayor recibiría la mitad y la otra mitad la dividirian entre sí los dos racioneros coadjutores. Las demás rentas asignadas 0 provenientes de las oblaciones de los fieles, misas, aniversarios, etc. se repartirian en cuarenta partes, de las que el abad mayor tomaria cuatro, cada una de las dignidades inferiores dos, cada canónigo una y media, cada racionero una y cada capellán media. La dotación del Duque de Feria para la Colegiata consistió en $\mathbf{5 0 0}$ ducados anuales y en la participación además en una serie de bienes ${ }^{3}$.

Por otra parte al Duque D. Gómez Suárez de Figuerosa y a sus sucesores en el Ducado de Feria, se le concedió el patronato perpetuo de dicha Colegial para la presentación del abad, dignidades, canonjías, raciones y capellanias y el nombramiento de los oficios, ministros y sirvientes de ellas, con la facultad de hacer durante su vida las constituciones conivenientes al régimen de la misma iglesia. Dos años después el

2 Usaba a diario hábitos morados y sombrero prelaticio con roquete, mantelete, anillo y pectoral; gastaba tunicelas blancas, encarnadas y negras, guantes y zapatillas blancas y encarnadas, y además medias moradas y blancas. VIVAS TABERO, Manuel, Glorias de Zafra o recuerdos de mi patria, Madrid, 1901, pp. 269-282, especialmente en p. 272.

3 Unas casas en la calle de Palacio de la villa de Zafra; el cercado del Conejal, que estaba lindando con el egido y la huerta del Pino; la dehesa llamada de la Corte de Solavilla en la población de Oliva de Jerez (Oliva de la Frontera), unas casas principales torreadas en la villa de Almendral; una batán (edificio en el que funcionaba una máquina generalmente hidráulica, compuesta de gruesos mazos de madera, movidos por un eje, para golpear, desengrasar y enfurtir los paños) y una tenería (curtiduría) en la villa de Priego y cuatro mesones en la villa de Cañete. Todos estos bienes los registró a nombre de la Colegiata el escribano de Zatra en el año 1613. Croche DE ACuÑA, Francisco, Crónicas de cabildos. Gacetillas o noticias cortas extraídas de actas de las instituciones capitulares de Zafra, Zafra, 1998. 
Romano Pontífice autorizó al obispo de Zamora D. Fr. Pedro Ponce para dar la colación canónica y posesión al primer abad D. Francisco Andrada, cuya ceremonia se verificó el 3 de abril de 1614. Con la creación de la Colegiata y en razón a los muchos derechos y prerrogativas que la Bula Pontificia otorgaba al abad sobre la numerosa clerecía de la Candelaria, se abrieron una serie de caminos que podian conducir a múltiples desacuerdos. Por una parte, estaba la oposición institucionada por parte del Patronato Real, que el rey tenía sobre la parroquia de Zafra, añadiéndole a éste, la exención que se le dispensaba a esta importante parcela de Zafra y su clero, ya que por este mismo documento se separaban de la jurisdicción del obispo de Badajoz.

Como caso muy especial, en esta villa se crearon dos jurisdicciones distintas entre los clérigos, pues, mientras una gran parte de ministros y capellanes quedaban incorporados a la recién creada Colegiata y dependientes del abad en todo, otra no menos numerosa comunidad de clérigos seguía teniendo como superior jerárquico al obispo pacense. Todos estos inconvenientes que comenzaron a vislumbrarse, ya desde sus inicios, fueron la base de los frecuentes pleitos, enemistades, problemas y escándalos, que azotaron a la Colegiata desde su institución. Los clérigos que no dependían de la Colegiata y tenían sometida su obediencia al obispo pacense, sumaban casi la treintena en la villa, y por aquello de, que seguian un camino distinto al de los prebendados y capellanes capitulares de la Iglesia Colegial, eran conocidos en la población con el mote de "clérigos extravagantes". Aunque tenian como inmediato superior al obispo, sin embargo, estaban al frente de iglesias, ermitas y oratorios como capellanes y rectores, e incluso, presidían las cofradías más entrañables de la vida religiosa de Zafra. Desde el primer momento «los extravagantes", que no participaban de los beneficios y honores de la Colegiata, exhibieron el argumento de su exención e invocaron el mismo documento papal de la Bula. Frecuentes colisiones tuvieron que existir, sobre los años 1615 y 1617, entre los pleiteantes locales, con la consiguiente apelación del abad ante el Nuncio, acerca de los pretendidos "abusos" y exigencias de los «clérigos extravagantes". El representante papal considerándose como valedor en tales conflictos para su apaciguamiento, y verdadero responsable de la defensa de los derechos de la Colegiata de Zafra, publicó un autoritario Breve o decreto que se recibió en Zafra el 17 de mayo de 1617. Sus órdenes eran tajantes a favor de la Colegiata zafrense y mandaba al obispo $D$. Cristóbal de Lobera «en virtud de santa obediencia y bajo pena de entredicho y multa de mil ducados, y a los demás con amenaza de excomunión mayor y 500 ducados de penali- 
zación» que no se inmiscuyese en estos asuntos y pleitos, y no procurasen ir contra los derechos del abad, aplicándose las anteriores penas con todo rigor si llegase el caso.

Desde los obispados de Jaca y Mondoñedo, vino a la diócesis de Badajoz el obispo D. Pedro Fernández de Zorrilla, que ocupó la sede pacense, entre los años 1618 y 1627. Desde el momento de su entrada en la demarcación eclesiástica, no cejó en sus pretensiones de recuperar la jurisdicción perdida, con la erección de la Colegiata de Zafra. El 14 de diciembre de 1618, se recibió en Zafra una carta suya, en la que trató de imponer una norma de conducta, en orden al uso de la jurisdicción. En virtud de Santa Obediencia y bajo pena de excomunión, mandó a todos los predicadores y confesores, sin excepción alguna, que en el periodo de 15 días debian comparecer ante el mismo obispo, con las licencias ministeriales que tuviesen en su poder, para examinarlos de su formación en las ciencias morales y renovarles las facultades. Con estas exigencias, surgieron las primeras reacciones del abad y cabildo de Zafra, que se consideraban exentos de tal requisito. Ante esta oposición el obispo elevó al Papa y a la Curia Cardenalicia un memorial, denunciando la potestad que se abrogaba el abad y no le correspondía. El abad fue llamado a Badajoz, para responder a los cargos que se le imputaban y fue puesto en prisión por orden del obispo Zorrilla 4 . Esto ocasionó varios pleitos de jurisdicción entre el obispo de Badajoz y la nueva Colegial de Zafra, oponiéndose también en 1619 el Fiscal del Consejo Real D. Diego Riaño Camboa, por considerar perjudicial esta erección al patronato que sobre esta iglesia ejercía el rey Felipe III. Algunos años después el rey Felipe IV nombró, después de oír a sus ministros, una Comisión de jurisconsultos eminentes para que le informasen sobre el particular, produciéndose como consecuencia una concordia entre el obispo de Badajoz D. Fr. Juan Roco de Campofrio, el duque D. Gómez Suárez, el abad y el cabildo de la Colegial el 24 de agosto y primero de septiembre de $1628^{5}$. Posteriormente y aun-

4 Croche de Acuña, Francisco, (La Colegiata de Zafra 81609-1851). Crónica de luces y sombras, Zafra, 1984, pp. 54-67.

5 . $P o r$ la que entre otras cosas contenidas en 23 capítulos, se convinieron en que la presentación del abad, arcediano, chantre y tesorero, se habia de hacer ante el $R$. Obispo para que les diese la colación y el título. Que sin embargo, de lo dispuesto en la bula de erección acerca de la unión de los beneficios simples, por su incompatibilidad y diferencias que habia habido entre la Colegial y el Arcipreste de la Parra que gozaba uno de ellos, no se habia de verificar respecto de éste, quedando para la lglesia el otro que se le agregó por muerte de Alonso Barrero que lo tenia; que la Iglesia renunciase a la obra pía de Pedro Hernández de Gerez y Maria Hernández su hermana, que se le había adjudicado en virtud de dicha bula, para que los patronos 


\section{que con alguna reticencia del Consejo Real, Felipe IV permitió la erección} de la Colegiata, que confirmó el Papa Urbano VIII con su Bula de Concordia, expedida en Roma el 13 de enero de 1631, y que el rey aprobó por Real Cédula de 18 de octubre de $1633^{6}$.

de ella tuviesen la mano y disposición que tenían antes de la erección, haciéndose lo mismo con todos los demás patronos así legos como eclesiásticos". Alegación en defensa del M.R. Arzobispo de Badajoz y del Cabildo de la iglesia Catedral de Zafra, sobre derecho de patronato de la Iglesia Colegial y presentación de sus dignidades, canonjías, beneficios, oficios y ministerios. AAMB, Zafra, leg. 89, n. 3.151, f. 3.

6 El documento tendía a moderar en algún sentido, las generosas concesiones del promulgado por Paulo V. Los principales puntos de su contenido venian a decir: Que han existido oposiciones por parte del obispo de Badajoz, a las gracias e indultos, y que, por otro lado, el Duque consideraba debian ser inviolables. Ambos quieren poner fin de forma amigable, a estas controversias y juntos han determinado la siguiente «concordia». Que la "primera instancia" en conocer delitos civiles y criminales de los prebendados y ministros, así como el de algunos serviciarios de la Colegiata, pertenece al abad. Que la segunda instancia es del obispo, o su tribunal, y en tercera, pueden ambas partes apelar al Pontífice, al Nuncio o al arzobispo Metropolitano. Que la persona del abad está exenta de la jurisdicción del obispo, a no ser que desobedezca los autos de la segunda instancia, en cuyo caso, puede obligarles el obispo con penas y censuras, pero nunca prenderle. Que el uso de los ornamentos pontificales abaciales, es decir, mitra, báculo, anillo y paramento, le es permitido usarlos dentro del ámbito de la iglesia colegial y en ocasión en diecisiete festividades principales del año litúrgico, y en otros casos, cuando lo faculte el obispo. Que el abad puede nombrar un cura párroco, de entre los canónigos, y dos coadjutores, de entre los racioneros, pero los debe examinar y darles licencias sacramentales el obispo. El abad no las puede dar, ni para predicar, ni para oficiar el sacramento del matrimonio. Que la visita pastoral ordinaria a la Colegiata le corresponde al obispo, como delegado de la Sede Apostólica. Este puede hacerla a la persona del abad y prebendados, revisar cuentas y fundaciones, por sí o por medio de sus visitadores, cuántas veces les parezca conveniente. Nunca se puede poner en prisión a la persona del abad. Que no ha de existir en la villa de Zafra el cargo de provisor o vicario del obispo,porque, aunque lo hubo en tiempos pasados, siempre fue ocasión de algunos disturbios. Que los duques presentarán al obispo los cargos de las personas, que han de ser nombrados: abad, dignidades y canónigos, y el obispo les dará colación o nombramiento a los elegidos. También los duques podrán designar al mayordomo de la fábrica, secretario, organista y demás músicos. Que para la elección de los canónigos magistral y doctoral, aquel que más voto haya conseguido entre los prebendados, será presentado por el duque al obispo. Que cuando el obispo venga a Zafra, a visitar la iglesia Colegial, tanto el abad como los prebendados, deben rendirle obediencia y reverencia, dentro y fuera de la iglesia de la institución colegial zafrense. Por último era lógico que esta Bula, viniese a traer paz y unión, así como establecer un "borrón y cuenta nueva", con el olvido de todo lo ocurrido anteriormente. Por ello, absuelve de aquellas penas y censuras eclesiásticas, en las que pudiesen haber incurrido, son sus actuaciones, tanto el obispo como el duque y los capitulares de la Colegiata, cerrando los viejos pleitos y controversias que quedaban atrás y obligando a todos a su nuevo cumplimiento, invalidando los actos que fuesen contrarios a ella. CROCHE DE ACUÑA, Francisco, o. c. pp. 73-74. 
Con arreglo a lo estipulado en la escritura de transacción, se desmembraron del cúmulo de rentas de la Colegiata las correspondientes a uno de los tres beneficios, que quedó agregado al Arciprestazgo de la Parra, con otras mandas pías y capellanías. Por esta razón, por la baja de los censos y por haber salido fallidas algunas otras rentas, quedó muy disminuido el capital donado por los fundadores para sostener la Colegiata. Entonces el cabildo recurrió al Duque, como patrono, para que remediase esta necesidad y después de muchas y reiteradas instancias, el 17 de agosto de 1748 convinieron D. Luís Antonio Fernández de Córdoba Duque de Medinaceli y de Feria y el licenciado D. Jerónimo Vicente de Torrecilla, canónigo y cura mayor de la Colegiata, en suprimir la dignidad de tesorero, cuatro canonjías, dos racioneros y dos capellanes, además el Duque regaló 1.000 fanegas de tierra en el marquesado de Villalba y 756 en Santa Marta. Igualmente se acordó pedir al Papa la reducción de misas rezadas, de forma que el cabildo con la misa conventual diaria, satisfaciese la obligación de cumplir con aquellas.

En este estado se hallaba la iglesia de Zafra cuando el 1 de julio de 1760 se expidió una circular, mandando a los arzobispos y obispos fijasen edictos para que todos los que tuviesen indultos o privilegios apostólicos para presentar beneficios eclesiásticos los enviasen a la Cámara de Castilla en un plazo de cuatro meses. El obispo de Badajoz dio el correspondiente aviso al Duque de Medinaceli y de Feria el 30 del mismo mes, mientras que el Fiscal D. Francisco José de las Infantas pidió al Duque la presentación de los citados privilegios concernientes a sus estados, llegándose a verificar esto después de muchas dilaciones ${ }^{7}$. El 5 de mayo de 1762 la Cámara de Castilla pidió información al obispo sobre la naturaleza del Patronato de la Casa de Feria en la Colegial de Zafra. Ocho días después el prelado manifestaba "que los Duques de Feria no fundaron, ni fabricaron a su costa la iglesia de Zafra, que la dotación con que el Duque tenía dotadas sus prebendas eran tan cortas que no merecía la adquisición del Patronato, que éste se había concedido a el Duque D. Gómez con la condición de verificarse el cumplimiento de quanto se habia ofrecido a Su Santidad por el mismo Duque, pero que era cierto que desde el principio de la erección no se cumplieron ni tubieron efecto muchas cosas de las prometidas y agregadas a ellas; en cuya consecuencia tampoco debió tener lugar el derecho de Patronato" 8 . Pues bien, una vez que el Señor Fiscal se hizo cargo de las Bulas de erección y concordia, y

7 AAMB, Zafra, leg. 89, n..$^{\circ} .151$, t. 5.

8 AAMB, Zatra, leg. 89, n. ${ }^{2} 3.158-t$, t. 3v. 
de los demás documentos presentados por el Duque, puso la correspondiente demanda el 7 de agosto de 1762 para que se declarase pertenecer al Real Patronato, la presentación de todos los beneficios de la iglesia de Zafra en los ocho meses apostólicos, reteniendo en la Cámara de Castilla las referidas Bulas y mandando que el Duque de Medinaceli y sus sucesores se abstuviesen de dichas presentaciones en lo sucesivo.

\section{EL PLAN BENEFICIAL DEL OBISPO D. MANUEL PÉREZ MINAYO EN 1770}

En el día 12 de junio de 1769, el rey Carlos III dio al conocimiento de la nación una circular, cuyo contenido iba encaminado a arreglar los beneficios eclesiásticos, distribuidos por todo el país, y que llegaban a gozar de una situación de tanto privilegio, porque sus actuaciones apenas eran fiscalizadas oficialmente. Según el Catastro del Marqués de la Ensenada, las propiedades de la Iglesia en Castilla representaban: una cuarta parte de las rentas agrícolas, un séptimo de las tierras de pasto y labor y un décimo del total de la cabaña nacional, con un total de dos millones de cabezas de ganado, frente a los veinte millones de todo el Reino. La mayor parte de las diócesis rebasaban los 100.000 reales de renta anual y alcanzaban el millón los arzobispados de Valencia, Sevilla, Santiago y Zaragoza. La Colegiata de Zafra, reunidos todos sus ingresos y rentas anuales, obtenía más ganancias que las de algunos obispados, pues alcanzaba la cota de 107.944 reales de beneficio anual.

A consecuencia de esta circular sobre el arreglo de beneficios incongruos, expedido por la Real Cámara en 12 de junio de 1769, el obispo de Badajoz D. Manuel Pérez Minayo publicó un edicto para todas las iglesias de su obispado, fechado el 23 de septiembre del mismo año, en el que daba algunas disposiciones respecto al cumplimiento de la circular del rey, comisionando al canónigo cura mayor Dr. D. Blas Gerónimo de Torrecilla, a fin de que se diese una exacta relación de las rentas de la Colegiata, número y dotación de sus individuos y fundamentos en que se apoyaba el patronato de esta iglesia a favor del Duque de Medinaceli. Basándome en la relación de los beneficios simples y préstamos del obispado según sus sinodales, se observa que en el Plan de 1770, había en Zafra dos beneficios simples uno agregado a la Colegiata y otro al arciprestazgo de la Parra, siendo las rentas de 2.558 reales cada uno, y además un beneficio curado. 
Cuando el obispo recibió el informe, remitió a la Cámara de Castilla, con fecha 12 de enero de 1771, el Plan general de uniones, supresiones y dotaciones que habia formalizado para todas las iglesias de su obispado. En lo que respecta a la Colegial de Zafra propuso que se suprimieran: una de las tres dignidades, cuatro de las doce canonías y dos de las ocho raciones que había en la iglesia Colegial, expresando que el producto de éstas, se invirtiera en las que quedasen vacantes, para obtener de esta forma una mayor congrua ${ }^{9}$. Habiéndose dado traslado al Fiscal, que entonces lo era el Conde de Campomanes, éste respondió que no sólo debía suprimirse una dignidad, cuatro canonjías y dos beneficios, según proponía el obispo de Badajoz, sino que debían suprimirse la mitad de todos los cargos, dignidades y oficios que se concedieron por la Bula de erección, a no ser que se encontrase algún medio para aumentarles la renta. La Cámara, por decreto de 4 de julio de 1772, se conformó con el parecer fiscal, y el Rey lo confirmó, dándose conocimiento de esto al obispo de Badajoz para su pronta ejecución y exacto cumplimiento. Sin embargo, D. Manuel Pérez Minayo murió sin llevar a cabo esta Real orden. El nuevo vicario capitular, licenciado D. Gabriel de Zalduendo, -conociendo las órdenes del rey en esta materia- se negó a dar la colación canónica de un beneficio y de una capellanía a dos sacerdotes presentados por el Duque de Medinaceli, pero al ocupar la silla de Badajoz D. Alonso Solis y Grajera, mandó un despacho al cabildo de Zafra haciéndole saber que en atención al nombramiento del Duque de Medinaceli, expedido a favor de D. Manuel Rodriguez Lozano, vecino de Toledo, para una capellanía vacante en la Colegiata, le había despachado el correspondiente título de adjudicación, mandando se le diese posesión. Enterado el cabildo de la orden del prelado, se opuso a ella, manifestando el 21 de abril de 1784 las razones que tenía para negar la posesión, a lo que el obispo respondió aprobando la resolución de los capitulares.

El 14 de julio de 1785, el mismo prelado despachó título de colación a favor de D. Francisco Arnate de una canonjía vacante por muerte de $\mathrm{D}$. Cristobal de Arce, pero el cabildo de Zafra le negó la posesión, enviando a Badajoz como delegados a D. Mateo Martínez del Río y a D. Domingo Alonso y Bernal, quienes expusieron al obispo las razones de la negativa. No se conformó el prelado diocesano con ei parecer del cabildo de Zafra, por entender que la supresión de cargos era para los nombrados fuera de la iglesia, pero que los posesionados debían tener ascenso según sus méritos, y por lo mismo dio posesión al señor Arnate el 18 de noviembre

9 AHN, Consejos, leg. 15.596, n. ${ }^{9} 6$, f. 1-2. 
del mismo año, mediante un despacho dirigido al abad de la iglesia y al Dr. D. Blas Gernónimo de Torrecilla, para que bajo pena de cien ducados y de excomunión mayor ejecutasen dicha decisión. Por la misma razón el obispo dio posesión de otros puestos a diferentes sacerdotes, entre ellos a D. Francisco Martínez de la Peña que era capellán de la misma iglesia. Pero el cabildo de la Colegiata, considerando perjudicial y arbitrario el proceder del obispo, envió a Madrid a D. Mateo Martínez y a D. Domingo Alonso y Bernal para que diesen cuenta al Rey de lo ocurrido. Por acuerdo del cabildo de Zafra con fecha 2 de enero de 1786, se le suplicó al rey que expidiera una Real orden para que el prelado se abstuviese de dar títulos de colación bajo ningún pretexto, y que se llevase a efecto la supresión decretada anteriormente.

\section{EL PLAN BENEFICIAL DEL OBISPO D. ALONSO SOLÍS Y GRAGERA EN 1786}

El 7 de febrero de 1786 se le envió al obispo de Badajoz desde la Cámara de Castilla, una copia de la representación que hizo el cabildo de Zafra. Don Alonso Solís y Gagera, el 15 de febrero se dirigió a D. Juan Francisco de Lastiri, haciéndole saber que enviaría el informe correspondiente que se le solicitaba y que llevó a efecto el 18 de febrero de ese mismo año, aduciendo en dicho escrito que si se realizase la anunciada supresión, su repercusión sería muy negativa para el pueblo ya que los oficios divinos se celebrarian «sin el decoro y la seriedad que exigian unas funciones tan sagradas» 10 . En consecuencia, la Cámara de Castilla

10 "Debo decir: Que siendo 32 los ministros de que se compone, por estatuto de ella, si se verificase la supresión intentada por algunos de sus individuos, se experimentaría con dolor de todo el pueblo la grave incidencia de celebrarse las horas canónicas, y oficios divinos, sin el decoro y seriedad, que exigen unas funciones tan sagradas, maiormente en los días de alguna solemnidad. El abad de dicha Colegiata, que por concesión apostólica goza de el privilegio de celebrar misa pontifical en ciertas festividades, apenas tendría entonces los ministros precisos para asistir a el altar y al coro, y en el caso de vacantes, sería necesario mendigar sacerdotes, que conrurriesen a la celebridad de ellas. Los piadosos testadores, que de veinte años a esta parte, han dotado abundantemente muchas funciones, a beneficio de sus almas, y considerable utilidad de dichos individuos, se verían defraudados de los sufragios, a que son acreedores de justicia, por haber hecho sus fundaciones en el concepto de ser 32 los sacerdotes, que habian de dirigir sus oraciones a el cielo, para impetrar el alivio de sus penas. - El mismo abad, y otros muchos prebendados de conocida bondad y juicio, que pesaron con prudencia estas razones, conocieron muy bien, quan perjudicial es a el culto divino, la reducción de ministros a un número tan corto y movidos del celo de Dios, $y$ honor de su Santo templo, me representaron y pidieron con la maior 
dio orden el 21 de junio de 1786 al obispo D. Alonso Solis y Grajera, para que sin esperar a la formación del Plan General de la Diócesis, pusiese en práctica el arreglo beneficial de la iglesia Colegial, oyendo instructivamente tanto al cabildo, como a sus patronos, fiscal eclesiástico del obispado y demás interesados, con arreglo a la circular de 12 de junio de 1769 , señalando a cada individuo la congrua dotación o sueldo que le pareciese justo al obispo si la que entonces percibian los miembros de la Colegiata no era suficiente.

En lo que respecta al beneficio simple de la Colegial que disfrutaba el Arcipreste de la Parra, el cabildo acordó el 24 de noviembre de 1786 que el citado beneficio debía volver a la Colegial por la incongruidad de estos beneficios, por consistir sus rentas en frutos decimales del término diezmatorio de Zafra y por estar comprendido en lo que se disponía en la Circular antes mencionada. En julio de 1791 formalizó la correspondiente demanda el cabildo ante el Tribunal de la Real Cámara -por hallarse vacante, al morir el entonces arcipreste Dr. D. José de Roxas- pidiéndole el correspondiente informe favorable al obispo D. Alonso Solís Gragera ${ }^{11}$. EI

eficacia, restituiese a la Iglesia a su antiguo estado, danto la colación de sus prebendas a varios sujetos que habia presentado su patrono el Duque de Medinaceli, en uso de el derecho que le toca. A vista de estas reflexiones, y teniendo presente, que los actuales ministros entraron en la posesión de su valor, me pareció más conveniente promover la honra de el Señor con el aumento de ministros, que adelantase la dotación de ellos con detrimento de el culto; bien satisfecho de que V.M. aprobaría una conducta tan proporcionada a el religioso celo con que su Real animo procura sea reverenciado su Santo Nombre, a que contribuie en gran parte la seriedad y solemnidad de las funciones eclesiásticas, que no puede verificarse con tan corto número de ministros. V.M. con su alta penetración, conocerá y determinaría lo más justo, y Yo lo ejecutaré con la exactitud que debo. Jerez de los Cavalleros en Santa Visita, 18 de febrero de 1786". AHN, Consejos, leg. 15.595, n. 9 , f. $25-26$.

11 “EI Dr. D. Blas Gerónimo de Thorrecilla canónigo de la Iglesia Insigne Colegial de la Villa de Zafra, y cura mayor de ella; el Dr. D. Antonio Bernavé Moreno, y el Dr. D. Juan Hilario Martínez, ambos canónicos, y el último magistral y curas coadjutores de la propia iglesia, que hace de única parroquia, como tales curas párrocos, y en virtud de nuestra representación parroquial, antes V.S.Y. con la devida atención hacemos presente: que por muerte del Dr. D. Josef de Roxas presbítero, se haya vacante el Arciprestazgo de la villa de la Parra, que comprehende vajo de dicho título el curato parroquial de la referida villa, con agregación de un beneficio dotado con frutos de la parroquial de nuestra representación, a saber parte de los decimales correspondientes a nuestro curato, de cuyas rentas, se desmembraron las suficientes para dotar dos beneficios simples, que el uno se hallá incorporado en el fondo de rentas de la expresada colegial, y el otro por indotación del curato de la referida de la Parra le fue agregado; y la subcesión de los tiempos y variación de las cosas, ha ahecho que el referido curato de la Parra titulado Arciprestazgo, antes incongruo, de presente esté superabundantemente dotado, alcanzando sus rentas, con inclusión de dicho beneficio, y el pie de altar, a mil ducados; $y$ el curato de nuestro servicio apenas 


\section{prelado, sin embargo, mediante una carta fechada el 9 de diciembre de} 1791 y dirigida al rey, no se mostró partidario con esta petición, aunque acataba la resolución real al respecto ${ }^{12}$. Ante la insistencia de la Cámara

llega a dos mil y cien reales, que son productos de las propinas de bautismos, casamientos y certificaciones de partidas, sin tener por curas, otra renta alguna, siendo la referida partible entre los tres; y computando la que a cada uno nos toca como tales canónigos, asciende a mil y quinientos reales de que es manifiesta nuestra indotación, y la sobrada de dicho Arciprestazgo; aun sin atender a que el pueblo de la Parra es reducido a poco mas de trescientos vecinos, y de menos necesidad de gastos para la subsistencia, y que el de nuestra situación es populoso, de mas de mil y setecientos vecinos; $y$ de mayor necesidad de sostenerse con mas expensas para vivir con la decencia que requiere el pueblo. $Y$ también es notable, que en la misma parroquial de la Parra, que en tiempo muy antiguo faltavan fondos para dotación de su párroco, y por ello se le agregó el veneficio de la parroquial de dicha villa de Zafra; con posterioridad se hizo tan pringue que de las rentas del curato, se desmembraron las suficientes para la fundación de dos beneficios simples que existen, el uno adjudicado a el Colegio de Maese Rodrigo de la Ciudad de Sevilla; $y$ el otro que goza $D$. Blas Minayo canónigo de la catedral de Badajoz, y quando el curato de la referida de la Parra no estubiera competentemente dotado o no lo quedase, teniendo lugar la pretensión que comprehenderá esta representación o súplica, tendría derecho a solicitar la reversión al fondo de rentas del curato, de dichos beneficios, o alguno de ellos, para quedar dotado con arreglo a la Real orden circular de doce de junio de mil setecientos sesenta y nueve. (...) $Y$ que en cumplimiento de la parte expresada de la citada Real orden, pues consta nuestra indotación y la sovrante de dicho Arciprestazgo, y que a nuestro cargo parroquial está la cura de almas, y la administración de sacramentos, a tan crecido número de feligrese de que se compone dicho pueblo de Zafra, se sirva V.S.Y. decretar la reunión, por reversión necesaria de dicho beneficio simple que de frutos de nuestra parroquia, ha tenido el cura o arcipreste de la Parra, concediéndonoslo para parte de congrua y dividirlo entre los tres, sin perjuicio de otras pretensiones que podamos entablar, para completo de nuestra congrua, o competente dotación: y pues la uftima vacante de dicho arciprestazgo se ha causado en mes cuya provision corresponde al Rey nuestro Señor, que se sirva V.S.Y. consultar a la Real Cámara de su Magestad para condescender a nuestra pretensión, con su disposición todavía que recurriremos a la misma superioridad con copia de este memorial, para solicitarlo y a tal fin". AHN, Consejos, leg. 15.596, n..$^{2} 6$, f. 36-37.

12 "Debo informar a V.M. que en la erección que se hizo de la Iglesia Parroquial de la villa de Zafra, en Iglesia Colegial a instancia del Duque de Feria, quedaron el abad, canónigos, prebendados y capellanes que la componen obligados a serbir al cura de almas por medio de un canónigo que había de ser el cura maior, y dos racioneros que habian de ser sus coadjutores, mediante haberse aplicado todas las rentas (que eran considerables) de el beneficio curado, a la dotación de las prevendas. Y por esta razón la cura habitual reside, no en los tres prevendados que an hecho su solicitud ante V.M., sino en todo el cavildo de la Iglesia Colegial, cuios individuos, como perceptores de aquellos frutos destinados a la congrua parroquial están obligados a retribuir a los fieles el pasto espiritual, sin que los tres párrocos por sí, tengan acción sin concurso de los demás individuos de pedir la restitución de el beneficio incorporado a el curato arciprestazgo de la Parra, por estar refundido el derecho del párroco en todo el cavildo de la Colegial. Este cabildo compuesto de treinta y dos individuos, no parece tiene derecho en calidad de párroco, a el aumento de dotación. Los frutos del beneficio curado si se consideran con separación de las demás rentas de la Colegial, son muy abundantes, y de valor tan superior, que si 
de Castilla para que ejecutara lo más pronto posible la orden pendiente sobre la Colegial de 1790, el obispo contestó el 13 de abril de 1792, pasando dicha solicitud al tribunal diocesano. El auto definitivo se concluyó el 31 de agosto de 1793. Sin embargo, el arreglo beneficial no llegó a verificarse, quedando en suspenso dicha reclamación.

\section{EL PLAN BENEFICIAL DE 1797}

Llegado a este punto ocurrió que el canónigo de la catedral de Badajoz, D. Francisco Mateos y Moreno, escribió al cabildo de Zafra en 14 de septiembre de ese mismo año, comunicándole que había conocido el arreglo beneficial de la Colegiata y que le parecía conveniente llegar a una solución factible entre el cabildo y el Duque de Medinaceli, a lo que estaba dispuesto a acceder el apoderado de éste $D$. Antonio de la Barrera. Por ello, el cabildo acordó suspender sus diligencias en el Tribunal Diocesano sobre la congrua y ponerse en manos del Duque, para que éste asignase a cada uno de los miembros del cabildo lo que le pareciera conveniente, «insinuándole que el medio de supresión sería gravoso al Cabildo por las muchas cargas que tenía que cumplir, y porque el culto de Dios decaería con la disminución de ministros a causa de que no podrían celebrarse los divinos oficios con el decoro y solemnidad como cuando era completo el número de capitulares creados por la Bula de Erección».

El expediente pasó a manos de los abogados del Duque que se encargaron de su estudio, hasta que el 31 de octubre de 1796 se resolvió, que el cabildo nombrase un apoderado para tramitar los puntos pendientes. Se nombró a D. Mateo Martínez del Río, dignidad de tesorero y a D.

se hallasen repartidos entre quatro curas, serian muy suficientes para mantenerlos con sobrada decencia. Y por lo mismo, estando el cavildo competentemente dotado en concepto de cura, no tiene acción tampoco a el aumento, aunque la tenga por otros títulos, como la está solicitando de su patrono el Duque de Feria. El curato arciprestazgo de la Parra, tiene su beneficio de Zafra unido, desde antes de la celebración dei Concilio de Trento, a lo que entiendo. Si se le segregase esta renta quedaría incongruo, y desnudo de la qualidad de dignidad de la Colegial de Zafra que tubo desde su erección, con asiento y lugar en el coro y capítulo. La fundación de dicha iglesia Colegial se hizo en el siglo proximo pasado vajo de este concepto, y no parece justo, que para dar incremento a las rentas de los prevendados, se disminuya la del arcipreste de la Parra, que según la regulación de el Plan de uniones es de 4.224 reales annuos, inclusa la de el beneficio de Zafra, agregado a el curato por indulto apostólico según tengo entendido. No obstante, V.M. con susabia penetración, determinará lo que juzgare mas acertado. Badajoz 9 de diciembre de 1791 ". Idem, f. 44-45. 
Franco Martínez de la Peña, racionero, que se desplazaron a Madrid y se presentaron ante el Duque el 16 de diciembre de ese año, y discutieran estos puntos, siendo el fundamental el estado de las rentas de la Colegial. Visto éste, el Duque de Medinaceli resolvió por decreto de 8 de marzo de 1797, suplir de sus rentas 71.631 reales y 2 maravedies, para dotación de la Colegial, con lo cual se completaba lo que tenía asignado cada beneficio, a saber: el abad 11.000 reales de vellón, 6.600 reales a cada una de las tres dignidades, 5.500 reales a cada una de las 12 canonjías, 4.400 reales a cada una de las ocho raciones, y 2.200 reales a cada una de las ocho capellanias. $Y$ que del sobrante de las rentas se aumentase a cada uno de ellos 50 ducados más, por ser demasiado reducida la de los 200 ducados ya señalados. Conforme el cabildo con esta resolución, se otorgó la correspondiente escritura de transacción y concordia. Sin embargo, por resolución posterior de 17 de abril de 1798 se concedió una nueva escritura en la que se hacía constar que el Duque daría anualmente 61.600 reales. A fin de atender a las necesidades de la Colegiata, y con la condición de que el cabildo habría de aprobar y firmar las Constituciones necesarias para el mejor orden y gobierno de dicha iglesia ${ }^{13}$. Dichas Constituciones fueron firmadas el 29 de septiembre de 1798 y fueron aprobadas por D. Felipe Casoni, arzobispo de Perge y Nuncio en Madrid el 29 de enero de $1799{ }^{14}$.

13 AAMB, Zafra, leg. 90, n.9 3.161, f. 123-126.

14 El cuaderno de Constituciones lo propuso el Duque de Medinaceli al Cabildo de la iglesia Colegial, y "éste acordó que se hiciese, y al efecto apoderó al Rmo. Sr. Abad Dr. D. José Martínez Torres, quien también con este motivo a invitación del Duque pasó a la villa y corte de Madrid, donde en unión con los abogados de Cámara de S.E. los diputados del cabildo, el Arcediano de Feria D. Franco Arnate, y canónigo Dr. D. José Gómez Cano, se acordaron los principales puntos de las Constituciones, y quedó encargado el $\mathrm{S} r$. Abad de hacerlo presente al Cabildo, luego que se regresase a su casa, y que por el mismo Cabildo se procediese al arreglo de lo demás». Para la elaboración de las Constituciones el cabildo se reunió el 20 de abril de 1798, "Y por quanto dicha Iglesia Colegial no tiene en el día constituciones de rigurosa observancia en algunas de sus partes, pues aunque se hicieron unas al principio de su erección por el Duque Gómez Suárez de Figueroa y posteriormente otras con anuencia y consentimiento de los Sres. Duques Patronos, por el Abad y el Cabildo de dicha Iglesia Coiegial por los años de 1669 y 1680 y otras en 9 de diciembre de 1709 no tienen las aprovaciones correspondientes que $S$. Santidad dispuso y en atención a que también han variado desde dicho tiempo las cosas y estado de dicha Colegial por quanto el Excmo. Sr. actual Patrono de ella D. Luis María Fernández de Córdoba, Lacerda, Suárez de Figueroa, Duque de Medinaceli, de Santisteban y de Feria (...) dispuso que se hicieran nuevas constituciones con arreglo al estado actual de dicha Colegial y que se presentasen al examen y aprobacion del Sr. Nuncio de S. Santidad en estos Reynos". En total el cabildo estableció 71 constituciones. En concreto la Constitución número 63 es la que mayor relación guarda con el tema beneficial, ya que en ella se especifica la manera 
La aprobación de las Constituciones sin la intervención del obispo de Badajoz, D. Gabriel Álvarez de Faria, ocasionó serios disgustos ${ }^{15}$ y motivó que el Duque enviase un oficio al cabildo de la Colegial solicitando "que en atención a que el cabildo no cumplia con lo estipulado en la Escritura de transacción y concordia, le devolviese esta citada escritura, quedando disueltas las respectivas obligaciones contenidas en ella» 16.

de repartir la hacienda de la Mesa Capitular, basándose en las asignaciones establecidas en la Bula de Concordia. Se detalla igualmente el plan de dotación y distribución de los 71.631 reales y dos maravedies que el Duque de Medinaceli concedió por dotación de congrua al abad, dinidades, canónigos, racioneros y capellanes de coro. Constituciones de la Santa Iglesia Colegial de Zafra. 1798, ADB, Zafra, leg. 89, n.² 3.141.-También existe una copia de dichas constituciones en el AHN, Consejos, leg. 15.597, n.. 1-2.?.

15 Al respecto D. Julián de Olarte, en nombre de D. Pedro Llobet, fiscal general del obispado de Badajoz, en los autos sobre el valor o nulidad de las constituciones que se habían firmado sin el consentimiento y aprobación del obispo, declaraba «que el conocimiento acerca de la formación de constituciones para el gobierrio de la iglesia Colegial de Zafra, su aprobación y observancia es privativo en primera instancia de la jurisdicción del ordinario diocesano (...) La iglesia parroquial de Zafra erigida ya en Colegial siguió como ha indicado en virtud de dicha Concordia y de los 23 capítulos que contiene, sujeta enteramente al Reverendo Obispo de Badajoz en cuyo territorio existe sin observar más ley que las referidas y las que le dictaba su propio prelado y pastor inmediato sin haber tenido otras Constituciones, pues aunque por la parte del Sr. Duque se dice se formaron varias en el principio y después por los años de 669, 680 y 709 o se quedarían en proyecto, o no llegarian a establecerse legítimamente (...) Considerándolas el obispo las constituciones ofensivas a su autoridad y jurisdicción privativa, nada conformes a la Bula de Concordia que gobernaba, con otros muchos defectos que contenian en la sustancia después de haber oído al fiscal por su auto de 25 de abril de 800 las declaró nulas con las actas capitulares que se celebraron para su formación, $y$ por ineficaz y vicioso el juramento prestado por el abad y otros a su observancia, mandando se archivasen y pusiesen las notas correspondientes, que el cabildo nombrase dos capitulares para que estendiesen un plan de otras que abrazasen todos los puntos, sin contravenir a las constituciones sinodales". AHN, Consejos, leg. 15.597, n.2 1, f. 224-240.

16 "No habiendo bastado los oficios paternales que he hecho para conseguir el arreglo de esa mis iglesia colegial, aun a costa de fecidos sacrificios de mi haciendo, y experimentando que, lejos de aumentarse la paz y buena armonía entre los individuos del cabildo con las nuevas constituciones que se han formado por él mismo con mi acuerdo e intervención, se han suscitado mayores discordias y desavenencias, no obstante estar firmados y consentidas dichas constituciones por todos los individuos capitulares, oponiéndose algunos de ellos con reparable inconsecuencia a su aprobación, habiendo otorgado poderes para contradecirlas formalmente ante el Nuncio, y aun ante el ordinario de Badajoz, excitando odiosas competencias con desaire de mis providencias, y faltando a lo que repetidas veces me tenian cfrecido, comprometiéndome para que resolviera lo que estimase más conveniente, todo lo cual ha sido sin efecto; no pudiendo yo mirar con indiferencia un procedimiento tan irregular, he resuelto alzar la mano en este asunto y suspender enteramente las resoluciones que tenía acordadas en beneficio de esa iglesia, lo que harás entender asi al abad y cabildo para su inteligencia, inediante haberse frustrado mis justas intenciones por las discordias y desavenencias de sus individuos, y a tl te servirá de gobierno para lo sucesivo". Vivas TABERo, Manuel, o. c., pp. 275-276. 
Dicho documento fue entregado por $\mathrm{D}$. Julián de la Peña al cabildo el 20 de noviembre de 1798. Diez días después contestaba el abad de Zafra pidiéndole al Duque que se hiciera cargo de nuevo de la Colegiata 17. EI Duque no contestó a este documento y entonces el cabildo, en unión de D. Alvarez de Faria, obispo de Badajoz, pusieron la correspondiente demanda a la Cámara de Castilla el 1 de octubre de 1800 contra el Duque de Medinaceli, no sólo por la incongruidad y falta de dotación, sino también por el derecho de patronato y provisión de las canonjías de la citada Colegiata, por corresponder al Rey según el Concordato. Dicha Cámara declaró en 19 de diciembre de 1801 que las Bulas de Paulo V y Urbano VIII estaban comprendidas en lo dispuesto por el Concordato, y por lo mismo todas las canonjías y prebendas debían de ser de presentación real en los ocho primeros meses del año, y en los cuatro últimos el obispo de Badajoz, reservándose al Duque de Feria la provisión de una canonjía y un beneficio en reconocimiento de sus antiguos derechos.

Naturalmente el Duque no admitió lo anteriormente expuesto y consideró muy perjudicados sus privilegios como único patrono de la Colegial por lo que envió al Rey una extensa exposición el 23 de marzo de 1802, explicando sus peticiones ${ }^{18}$. Sin embargo, el Rey no las atendió, y conti-

17 «Excmo. Ser: Habiendose juntado este Cabildo para leer un oficio que con fecha del día 20 del corriente se le pasó por el contador de V.D. D. Julián de la Peña, en que incluía una orden de V.E. del día 14, habiéndole sido muy sensible tan infausta noticia, ha acordado lo que verá V.E. por el testimonio que a la letra que acompaña a ésta, y en su consecuencia suplica rendidamente a V.E. que, sofocando en su generoso ánimo los disgustos ocurridos, por un efecto el más propio de su grandeza y alto carácter, levante la suspensión de sus benéficas providencias, y vuelva a poner su poderosa ano en los negocios pendientes, para más brillo, ostentación y reconocimiento de sus inalterables piedades y religioso celo del culto divino. Lo que asi espera este Cabildo de la piedad y magnánimo corazón de V.E. y que perdonándole cuanto haya hecho en desagrado de V.E., pues nunca ha sido su ánimo faltarle en lo más mínimo. 30 de noviembre de 1798, José Abad de Zafram

18 "Señor: El Duque de Medinaceli, Santisteban y Feria, P.A.L.P. de V.M. con el mayor respeto, dice: que en últimos de diciembre del año próximo pasado puso en manos de V.M. una larga y reverente presentación exponiendo el pleito que se había suscitado en el Tribunal de $V$. Cámara Real a instancia del Fiscal de ella, del R. Obispo de Badajoz y del Cabildo Colegial de Zafra sobre el patronato y presentación de las prebendas de la misma iglesia, el cual, después de diversos trámites, se había decidido por la Cámara y remitido a consulta a V.M. y con el motivo de haberse precipitado extraordinariamente la sustentación de dicho expediente, coartándole al Duque los términos de poder ejercer sus probanzas, que quedaron incompletas, priuvándole de otros legítimos medios de defensa que podian y debian influir para la más justa determinación de este asunto, suplico a V.M. en fuerza de los fundamentos que expuse se digne expedir la Real orden correspondiente para que otro Tribunal de la Cámara, reponiendo las cosas al estado que tenían al tiempo de la prueba, conceda al Duque los términos competentes para ejecutar 
nuó el Duque presentando canonjías y beneficios, sin tener en cuenta el decreto de la Cámara Real. Por otro lado el obispo de Badajoz siguió negándoles la colación canónica y el abad de Zafra no quiso darles la posesión, quedando por este motivo reducido el cabildo a muy pocos individuos 19 .

Por tanto todo quedó en suspenso, y el día 11 de abril de 1802, falleció el obispo D. Gabriel Álvarez de Faria. Un mes antes sucedieron desavenencias serias entre el obispo y el abad D. José Martínez de Torres, a consecuencia de las cuales éste fue puesto en prisión. Cuando tomó posesión de la diócesis D. Mateo Delgado Moreno, el abad de Zafra estaba aún en prisión, y entró en los propósitos del nuevo prelado el que permaneciera en esta reclusión. El día 1 de marzo de 1803, el rey Carlos IV, a instancias del Príncipe de la Paz, publicó una Real orden, por la que se le alzó la reclusión, pero cuando se intentó poner en práctica la excarcelación del abad, de nuevo el obispo se resistió a concedérsela, hasta ver personalmente la misma, aunque al final accedió a lo ordenado. En los primeros días del mes de marzo de 1803, el abad por fin regresó a Zafra,

\footnotetext{
"ex integro" y completar las que estimase conducentes a su legitima defensa. No tuvo el Duque el consuelo de que V.M. se dignase diferir a esta, en su concepto, tan justa petición: antes bien, por su Real resolución se conformó con el dictamen de la Cámara, por el que se declara que los Breves Apostólicos, expedidos por la Santidad e Paulo V en 10 de diciembre de 1609 y Urbano VIII en 13 de enero de 1631, que son los de Erección y Concordia de dicha Iglesia Colegial, están comprendidos en la disposición del Concordato celebrado con la Corte de Roma, y que a su consecuencia, deben ser de presentación Real la Abadía de la misma colegiata en todas sus vacantes, y las demás dignidades, canonjías y prebendas en los ocho meses y casos de las reservas especiales iguales, $y$ en los otros cuatro el $R$. Obispo, reservando sólo al Duque en consideración a las cantidades con que ha contribuido para la dotación de dicha iglesia, una canonjia y una ración, y no conformándose se le reserva su derecho para que use de él como convenga.(...) Llevado de esta consideración, luego que se publicó en la Cámara vuestra resolución, interpuso el suplicante en el mismo tribunal el correspondiente recurso de súplica solicitando se le admitiese lisa y llanamente en abmos efoctos, en la forma ordinaria, a que por decreto de 10 del corriente mes de marzo se ha provisto que el Duque recurra a V.M. (...) Por tanto, suplica a V.M. se digne expedir la correspondiente Real orden para que la Cámara admita lisa y llanamente y en ambos efectos la súplica que tiene interpuesta de la citada primera sentencia que ha recaído en el mencionado pleito sobre el patronato y presentación de las demás prebendas de la citada Colegial, oyendo el Duque en esta segunda instancia las excepciones, probanzas y defensas que propusiere para aclarar su justicia y derecho". VIVAS TABERO, Manuel, o. c., pp. 277 . 279.

19 «Siendo en el día existentes, tres canónigos, cinco racioneros y seis capellanes de coro, con la circunstancia de que tres de los racioneros a causa de sus achaques habituales, asisten muy poco al coro y divinos oficius, de que resulta menos solemnidad y decoro en el culto y más aumenio de trabajo para los demás".
} 
con la expresa orden episcopal de que no hiciese uso de sus antiguas atribuciones de la dignidad abacial y se abstuviese de vestir ornamentos pontificales.

El tema sobre el derecho de patronato de la Colegial y la presentación de todas las dignidades, canonjías, beneficios y oficios siguió latente en años sucesivos. Sobre este particular he encontrado un documento en el Archivo del Arzobispado de Mérida-Badajoz, firmado por el abogado D. Isidoro Merelo, fechado el 23 de diciembre de 1807 e impreso en Madrid, que es una alegación en defensa del obispo de Badajoz y del cabildo de Zafra para que se confirmase el Decreto de la Cámara de 19 de diciembre de 1801. De dicho documento comento algunos aspectos que considero importantes y que guardan estrecha relación con el patronato. En principio dice que la Corona es la principal interesada en este pleito, fundando su intervención en las disposiciones del derecho real y eclesiástico, y que por lo tanto el obispo y el cabildo no hacen más que coadyuvar la acción intentada por parte de la misma Corona. Al respecto aduce que el que intenta adquirir el derecho de patronato por «usurpación» ofende a la Corona y a la Iglesia, ya que la fundación y dotación es la única causa o título con que legítimamente puede adquirirse semejante derecho. Por tanto considera que la Bula de erección de 10 de diciembre de 1609 no pudo servir para adquirir dicho patronato, porque además de la construcción de la iglesia, tendría que haber señalado el Duque de sus propios bienes laicales patrimoniales, las rentas necesarias para el adorno de la misma, la manutención de sus ministros, luces y demás gastos necesarios para la celebración del culto, sin embargo, la parroquia ya existía 20 , con su curato, beneficios simples, capellanias, etc. y la dotación que hizo D. Gómez Suárez de 500 ducados de renta anual era insuficiente para tal fin. La confirmación del Papa fue condicional y no podía producir efecto sino se cumplían los siguientes requisitos, esto es, si no eran ciertas las rentas propuestas, si no ascendían a la cantidad que se había manifestado y estimado suficiente para la dotación de la Iglesia y su cabildo, o por si alguna causa no podía tener efecto la reunión y agregación de todas ellas. Nada de lo estipulado -según palabras del mencionado licenciado- llegó a cumplirse. Apostilló al respecto que si el Conde D. Gómez fue tan escaso en ofrecer, mucho menos fueron sus sucesores en cumplir lo ofrecido. Por otro lado, la donación de 1748 no pudo suplir los defectos anteriores ni mejorar el de-

20 El edificio se construyó en 1545, a expensas de D. Pedro Figueroa, conde de Feria, con motivo de haberse arruinado la iglesia antigua. Fue consagrada en 24 de marzo de 1546, por el IImo. Sr. Trujilio, obispo de Badajoz, y al día siguiente se colocó el Santísimo Sacramento. 
recho de la Casa de Feria, ya que a finales del año 1807, ésta debía a la Colegial un total de 547.318 reales y 31 maravedíes 21 .

Sobre las desavenencias producidas por el derecho de patronato sobre la Colegial de Zafra y la provisión de sus prebendas, se redactó un «Memorial» 22 que se conserva en el Archivo Histórico Nacional, que considero importante por la relación histórica que hace del mencionado pleito. Como antecedente del mismo se remontaba a la circular de $1 .{ }^{\circ}$ de julio de 1760 por la que el Duque de Medinaceli presentó en la Cámara de Castilla dos bulas: la de Paulo V de 10 de diciembre de 1609 y la de Urbano VIII fechada el 13 de enero de 1631, enlazando este hecho con el Decreto de 19 de diciembre de 1801. Seguidamente se fijan las pretensiones de las partes interesadas: el Duque (buscando el derecho de presentación de los miembros de la Colegial sin ningún tipo de restricción), el Arzobispo-Obispo de Badajoz y el cabildo de Zafra (queriendo la confirmación con costas y determinación del decreto de 19 de diciembre) y el fiscal, que con fecha 1 de septiembre de 1807 dijo haberlo pasado a la Cámara de Castilla para que confirmara el anterior decreto. Para la consecución de estos objetivos el Duque de Medinaceli y el Obispo presentaron las pruebas pertinentes. En este orden de cosas es el Duque quien más se extendió, ya que presentó las circunstancias históricas sobre la fundación de la Colegial, la dotación que le hizo, la relación de las capellanías fundadas por los "causantes" del Duque y las rentas y fincas pertenecientes a dicha institución en diversas localidades (Villalba, Santa Marta y Solana).

Como respuesta a la mencionada alegación del obispo de Badajoz, se imprimió en Madrid, con fecha 3 de marzo de 1808, la defensa legal del Duque de Medinaceli ${ }^{23}$, que fijó su objetivo en un único punto, declaran-

21 Alegación en defensa del M. R. Arzobispo Obispo de Badajoz y del Cabildo de la lglesia Colegial de Zafra, sobre el derecho de patronato de la Colegial y presentación de todas sus dignidades, canonifas, beneficios, oficios y ministerios, pretenden que se confirme con costas el Decreto de la Cámara de 19 de diciembre de 1801... AAMB, Zafra, Colegiata, leg. 89, n. $3.151,29$ folios. Otra copia impresa de este mismo documento se encuentra en el AHN, Consejos, leg. 15.599.

22 Memorial ajustado formado con citación y asistencia de las partes y mandado imprimir por Decreto de la Cámara, para la vista en segunda instancia del pleyto que en ella pende y sigue el Duque de Medinaceli y Feria, con el Señor Fiscal Don Simón de Viegas, el muy Reverendo Arzobispo-Obispo de Badajoz, y el Cabildo de la lglesia Cologial de Zafra, sobre el derecho de patronato de dicha lglesia Colegial y provisión de sús prebendas. Madrid, MDCCCVII. AHN, Consejos, leg. 15.599, n. 1-9.

23 Defensa legal por el Duque de Medinacell y otros títulos en el pleito que sigue en la Cámara con el Sr. Fiscal, el M.P. Arzobispo Obispo de Badajoz, y el cabildo de la lglesia Colegial de la villa de Zafra; sobre el derecho de patronato de la misma iglesia y presentación de sus prebendas. Madrid, MDCCCVIII. AHN, Consejos, leg. 15.599. 
do que el patronato de la Colegial de Zafra y el derecho de presentar sus dignidades y prebendas en todas las vacantes que se produjeran, no estaba sujeto a las derogaciones apostólicas, ni a las disposiciones del Concilio de Trentro ni a las del Concordato de 1753.

\section{ZAFRA DURANTE EL PONTIFICADO DE D. MATEO DELGADO MORENO (1816-1820)}

A consecuencia de una instancia efectuada por D. José Gómez Cano y D. Leonardo de Luna, racionero, dirigida a la Regencia del Reino indicando el pleito que había con el Duque en lo referente al patronato de la Colegial, recibió el cabildo un escrito fechado en Cádiz el 9 de abril de 1813, por el que pedía se le informase de la situación en que se encontraba la demanda pendiente. El 10 de agosto de 1813 se le envió a D. Antonio Cano Manuel una información general y resumida de lo ocurrido desde su fundación hasta ese momento para terminar diciendo que a partir de 1801 el Duque continuó expidiendo títulos para las vacantes que se iban produciendo, y a pesar de que los interesados no solicitaron su colación, no la hubieran logrado, por no hallarse suficientemente dotadas, según proveían las Reales Cédulas expedidas sobre reunión y supresión de beneficios. Además se pedia una resolución rápida de la citada demanda para poder efectuar el arreglo parroquial de la iglesia 24 .

Tres años después, y mediante la Real orden de 13 de diciembre de 1816, se le solicitó a $D$. Mateo Delgado que informase de nuevo sobre la situación de la Colegial, debido a las instancias que enviaron al Rey el canónigo D. Miguel Tomás Vidaurreta ${ }^{25}$, junto con seis prebendados más y con D. Ramón Crespo y D. Pedro Carmona, procuradores síndicos general y personero de la villa de Zafra, en los días 13 y 17 de marzo y 22 de mayo de 1815, solicitando que se proveyesen de ministros su iglesia, que se siguiera conservando el título de Colegiata, y que se diese colación e institución canónica a los nombrados por el patrono para las vacantes que existían, debido al reducido número de los miembros del cabildo 26.

24 AAMB, Badajoz, Mitra, leg. 13, s/n.

25 Nombrado por D. Luís Joaquín Fernández de Córdoba, Duque de Medinaceli, en Montilla el 17 de enero de 1816.

26 D. Ramón Crespo y D. Pedro Carmona procuradores síndicos, general y personero de la villa de Zafra(...) "Diecisiete años hace que no accediendo el R. Obispo de Badajoz a dar colación a los sujetos nombrados en prevendas vacantes en la Colegial se fue minorando su número de 
Como consecuencia de ello el Obispo emitió un informe el 12 de marzo de 1817, en el que volvía a dar los antecedentes del pleito mantenido durante casi doscientos años sobre el patronato. En él comentaba que a raiz de la circular de 12 de junio de 1769 sobre aumento de congrua y arreglo del plan beneficial, se efectuaron los correspondientes autos, pero al parecer se extraviaron durante la Guerra de la Independencia por el robo de documentos que padeció el archivo parroquial durante la contienda. El obispo ratificaba la incongruidad de sus ministros sobre todo debido a la acción destructora de la guerra desde el año 1808 «después de haber sido vendidas, en virtud de las Reales órdenes, la mayor parte de las alajas y hechos redenciones de censos cuyos capitales están sobre la Renta del Tabaco y en el Crédito Público» 27. Llegaba a la conclusión de que la causa de la suspensión de la colación de los beneficios era la falta de dotación, por tanto consideraba que el único medio para poner solución a este estado de decadencia era el arreglo de un nuevo plan beneficial 28.

forma que el curato que el canónigo y dos prebendados serían con tanto celo y exactitud y con no menos interés del pueblo, hoy lo hace un sólo canónigo anciano y encargado de otras comisiones de la propia igiesia, que le ponen en necesidad de precisas ausencias, en cuyo caso, y aun sin él, fía su principal encargo al de un sacristán, que sobre no ser lo bastante para la puntual asistencia, se nota la gran diferencia de decoro en el servicio, no siendo menos reparable que la falta de prevendas que hoy se experimenta devilita tanto la magnificencia de las festividades, que las más solemenes no se celebran como cabe, hechos que en las primeras ocasiones que ocurrieron han conmovido el celo religioso del pueblo. (...) Continúa Sr. el pueblo sin la asistencia de cura a sus feligreses (...)se verifican casos de faltar a los fieles los auxilios espirituales en sus últimos momentos. Todos estos males provienen indudablemente de la falta de individuos de que se resiente el cabildo colegial. (...) Sospechan los representantes con algún fundamento que fines particulares se dirijan a que cese la colegial, y quede sólo en parroquia (...) Zatra 17 de marzo de 1815m. Expediente a instancia de D. Miguel Tomás Vidaurreta sobre colación de la abadía de la iglesia Colegial. AAMB, Zafra, leg. $89,{ }^{9} 3.158 \mathrm{~h}$.

27 "En cuanto a la enajenación de alhajas son tres la vendidas, a saber: una casa en la calle de Sevilla a Manuel Cordero en 330 reales de vellón. Otra al mismo en la Calle de Cerrageros en 5.600 reales y una tierra en término de los Santos al sitio de la Albuja a D. Diego Mansera en 3.330 reales. Además de la necesidad urgentísima en que se vio el cabildo de socorrer, con el producto de referidas ventas a sus individuos y subalternos contribuyó también el que la casa Calle de Sevilla amenazaba ruina por algunas de sus principales paredes y techos, y la de la CaIle Cerrageros esta cuasi del todo destruida a falta de todas sus puertas y sin más techo que el superior; y el cabildo se hallaba sin fondo alguno para ocurrir a sus reparos. La tierra no constaba en los libros de hacienda ni de ningún producto en los de cuentas, estando como olvidada por su mala calidad y distancia, por lo cual el cabildo acordó su enagenación».Zafra 14 de enero de 1813. AAMB, Zafra, leg. 89, n..$^{9} 3.154$.

28 AAMB, Zafra, leg. 89, n. ${ }^{9} 3.158 \mathrm{~h}$. 


\section{La elaboración del nuevo reglamento de la Colegial fue mandado ha-} cer por el entonces provisor D. Rafael Blázquez Prieto -mediante el auto de primero de julio de $1816^{29}$ - a D. Miguel Tomás de Vidaurreta. Por ex-

29 «En la ciudad de Badajoz a 1 de julio de 1816. El Sr. Provisor oficial y vicario general de este obispado, habiendo considerado la necesidad y utilidad de tener reunidas las noticias del estado actual de todas y cada una de las parroquias de esta diócesis especialmente para proceder al arreglo de ellas, conforme a la carta circular del Supremo Tribunal de la Cámara de 12 de junio de 1769, y otras Reales órdenes posteriores, a la manera que se halla referido el respectivo insinuado estado actual en los reglamentos impresos de las parroquias de la Torre, la Albuera y Villagarcia, Olivenza, San Jorge de Alor, Santo Domingo de la Contienda, Villarreal y Táliga, y atendiendo a la presentación certificación acerca de la insigne iglesia colegial única parroquia de la villa de Zafra de este obispado, dijo S.S. ante mi el infrascripto Notrio mayor de este Tribunal Diocesano, que confería y confiere, comisión al Dr. D. Miguel Tomás Vidaurreta para que disponga que el caibldo de la referida iglesia, atemperándose al método observado en los citados reglamentos impresos, las Reales Cédulas auxiliatorias para su ejecución, y tomando extrajudicialmente todas las noticias convenientes, extienda un informe claro y circunstanciado con especificación y exactitud acerca de su iglesia colegial y parroquial, a cual santo está dedicada; quantas casa o familias hay en ellas; quantas almas de comunión, quantas de sola confesion, y quantos párvulos. Que dignidades, canonjias, raciones, beneficios, capellanias y otros empleos de sacristanes, monaguillos y demas dependientes hay en la misma iglesia; quien los nombra y quales son las cargas y obligaciones, rentas y utilidades de cada uno, y en quanto a los diezmos y primicias de dicha Iglesia se expresará si no se recaudan, administras y distribuyen, que porción toca a cada partícipe, quienes nombran los cojedores, administradores y repartidores y con qué dotación y emolumentos; quantas fanegas de trigo ay de diezmo y primicia hay en cada año, y quanto de las demás especies de frutos decimales, haciendo un computo prudencial; $y$ en quanto a la fábrica de iglesia se expresará quales sean y a quanto asciende sus rentas, quantos sus gastos ordinarios en cada año, que caudal tiene a su favor en créditos, dinero y efectos vendibles y si está empeñada o necesitada de obras, reparos y ornamentos, y en quanto a aniversarios, $y$ fundaciones de misas perpetuas, y qualesquiera bienes pertenecientes a la iglesia, y su cabildo y demás ministros se expresará a quanto ascienden sus capitales, y sus réditos, quienes perciben estos y por qué nümero de misas cantadas y rezadas, $u$ otras cargas, $y$ acerca de las cofradías o hermandades, se expresarán los instrumentos de su fundación y de la aprobación Superior, qual es su instituto, las rentas, los sufragios, ofunciones que se hacen, que limosnas se dan y quien las percibe, y en quanto a las capellanias se hará una circunstanciada relación de sus fundadores y poseedores actuales, sus cargas y rentas y a quien pertenece su patronato, y en quanto a las hermitas se expresará a que Santo están dedicadas, su situación dentro y fuera del pueblo, que bienes y rentas les pertenecen, quienes son los administradores, y por quien son nombrados, estendiendose a dar igualmente alguna noticia de los conventos de regulares, su instituto, e individuos con todo lo demás que se ofrezca, y conduzca a dar la más completa circunstancia, y exacta idea de todo lo eclesiástico de la villa de Zatra; disponiendo asimismo el Juez comisionado de acuerdo con el cabildo, que por cualquiera Notario o Escribano Real se estiendan testimonios literales o en relación bastante de las providencias Pontificas, Reales, Espiscopales y Judiciales y de qualquiera otras escrituras que hubiese y conduzca a ratificar el más antiguo astado de la iglesia, y el sucesivo hasta el presente». D. Gabriel Rafael Blázquez Prieto. Ante mi Josef Ramos, Notario Mayor. AAMB, Badajoz, Curia, leg. 3, n. 1, f. 1-2. 
cusa de ese prebendado, se comisionó por auto de 31 de agosto del mismo año al Dr. D. José Gómez Cano, como presidente del cabildo, quien por medio de los oficios de 27 de julio y 12 de septiembre de 1818, confirió a D. Juan Moreno Cordero -presbítero fiscal eclesiástico de la villa de Zafra- todas las facultades necesarias para que ejecutase el citado auto de $1 .^{\circ}$ de julio, con ayuda del escribano D. José Calafanz Cruzado. El fiscal envió un escrito al cabildo el 24 de marzo de 1819, solicitándole la información pertinente, y éste acordó su cumplimiento el 26 de marzo. El 20 de abril el fiscal requirió de nuevo el envío del expediente, fijándole un plazo de 20 días. El 11 de mayo volvió a insistir asignándosele otros veinte días para la entrega. A esto el cabildo contestó que no podía elaborar dicho expediente en tan poco tiempo. Al unísono se dirigió a D. Mateo Delgado Moreno para solicitar una nueva ampliación del plazo previsto y hacerle saber que el cabildo estaba trabajando activamente en la recopilación de datos, pero era una labor muy complicada por el estado en que quedó el archivo de la Colegial, después de la Guerra de la Independencia, al igual que la hacienda de esta iglesia, por la ruina de algunas de sus propiedades, menoscabo de otras y redenciones en virtud de Reales decretos. Exponían a título comparativo que en el plan beneficial que se formó en 1797, se emplearon más de ocho meses, trabajando en él cuatro prebendados, en unión con el abogado y contador del Duque de Medinaceli, auxiliados a su vez por los oficiales de la contaduría del citado Duque, a pesar de que ese plan se reducía únicamente al estado de las rentas de su mesa capitular y la distribución de ellas entre los individuos del cabildo y sus capellanes de coro.

Solicitó igualmente al Prelado, que nombrase a alguien de su confianza para la elaboración del informe correspondiente a las ermitas y capillas de esta villa, así como de las hermandades, cofradías, capellanías, memorias de misas y otras fundaciones piadosas que no estuviesen bajo la dependencia del cabildo ${ }^{30}$. D. Mateo Delgado les amplió el plazo a tres meses mediante decreto de 28 de junio, aunque el cabildo solicitó de nuevo el 27 de septiembre de 1819 un nuevo aplazamiento de dos meses. Por fin el 31 de enero de 1820 envió D. Juan Cordero toda la información recopilada durante estos años lo que permite reconstruir aspectos de la vida en la villa de Zafra.

Según el reglamento, Zafra tenía 1.085 casas, de ellas 70 estaban arruinadas por los efectos de la Guerra de la Independencia, 72 dispersas en huertas y casas de campo y 46 en el arrabal de la Lapa. La po-

30 AAMB, Zafra, leg. 90, n. ${ }^{9} 3.161$, f. 70-71. 
blación global era de 1.439 vecinos. De éstos, 4.669 personas de comunión, 357 de confesión y 695 párvulos, todos feligreses de la iglesia colegial, que era la única parroquia de esta población. Se contabilizaban además un total de cuatro ermitas en la misma villa: una contigua a la Colegial dedicada a San José ${ }^{31}$, que servía en casos accidentales de ayuda de parroquia. Otra situada en la Puerta de los Santos bajo la advocación de la Virgen de la Concepción y del Amparo 32, la tercera en la Puerta de Sevilla con la advocación de la Virgen Santísima, con el título de la Aurora y la última en la Puerta de Jerez, con el título de Virgen de la Caridad ${ }^{33}$. Fuera de la población había otras dos ermitas: la de Belén ${ }^{34}$ y la de la Concepción y San Román ${ }^{35}$. Habia también tres hospitales: uno con el título de Santiago, para toda clase de enfermedades ${ }^{36}$, otro de San Miguel para la curación de enfermedades venéreas ${ }^{37}$, y el

31 Era «una iglesia pequeña contigua a la Colegial y parroquial con sacramento cuando los fieles costean el alumbrado de la lámpara, porque no tienen renta que puedan dedicarse al efecto. En esta iglesia se reza a la oración el Santo Rosario, después salen los devotos alabando a la Virgen públicamente por las calles y plazas. Hay una cofradfa compuesta de un capellán, dos mayordomos $y$ seis vocales, que anualmente se eligen. Su instituto es enterrar a los hermanos que mueren de 110 que son, los que al efecto contribuyen con $10 \mathrm{rs}$. annuos". Fue aprobada por el llmo. Sr. Obispo D. Juan María de Rodezno. Idem, f. 162.

32 "No tiene rentas, pero está decentemente surtida de ropas. Tiene una capellania, cuyas rentas deben invertirse en misas los domingos y dias de fiesta. Capellán D. Juan Montano, nombrado por el Obispo de Badajoz". Idem, f. 169.

33 "No tiene renta y se sostiene con las limosnas de los fieles". Idem, f. 169.

34 "La ermita de Nuestra Señora de Belén está situada extramuros de esta villa como a medio cuarto de legua. Fue destrozada en la invasión francesa y reedificada por su administrador $D$. Juan Moreno Cordero. Solo tiene 13 reales de censo que anualmente paga Francisco Javier Navarro, y algunas otras cantidades en el Crédito Público y nombra su administrador el obispo de Badajoz. EI Dr. D. Leonardo de Leria, disfruta una capellanía por derecho de familia con la obligación de celebrar misa rezada los domingos y dias de fiestam. Idem, f. 169.

35 "La ermita de San Román, extramuros de esta villa, e inmediata a la población. Fue destrozada en la invasión francesa y asi permanece. Tiene un capital de 3.000 reales que existe en poder de los herederos de $D$. José Lobato presbitero, que los mando en su testamento para la reedificación de dicha ermitam. Idem, f. $163 \mathrm{v}$.

36 "En la calle de Santiago hay un hospital donde se curan todos los pobres de solemnidad, y le asisten a toda clase de alimentos y medicina. Es su perpetuo patrono el Duque de Medinaceli, nombrando a su administrador capellán y demás que asisten a los enfermos. El capellán actual es D. Fernando Ramírez y el administrador D. Antonio Casa. Hay una iglesia pequeña con los Santos Sacramentos para administrartos a los enfermos de este hospitah. Idem, f. 164. Pascual Madoz dice que tiene 13 reales de renta aproximadamente que se emplean en medicinas y alimentos, para 48 pobres poco más o menos, que recibe al año y en los sueldos de administrador, capellán, médico, sangrador y enfermero. Diccionario histórico geográfico de Extremadura, vol. IV, p. 297

37 "En la calle de San Miguel hay un hospital dedicado a la curación de entermos del mal venereo. Lo fundó D." Cecilia de Arenzana, constituyéndose patrona y a su nombre sus descendientes 
último de San lldefonso dedicado a la convalecencia de enfermos ${ }^{38}$. Los tres poseían iglesia.

También se contabilizaban tres conventos de regulares: uno de la orden de Santo Domingo (con 6 religiosos sacerdotes, uno lego y un donado) ${ }^{39}$, otro de la orden de San Francisco (con 14 sacerdotes, 4 legos y 2 donados) 40 y el tercero un convento de religiosos descalzos, cuya comunidad se componía de 10 sacerdotes, 3 legos y 3 donados ${ }^{41}$. Y seis conventos de religiosas, dos de ellos de la orden de Santo Domingo, tres de la orden de San Francisco (sujetos todos ellos a sus respectivos diocesanos), y uno de Carmelitas dependiente del obispo. La única parroquia en Zafra fue la erigida en Colegial -bajo el título que anteriormente tenía de Santa María Candelaria- por bula del Papa Paulo V de 10 de diciembre de 160942 .

\section{Las cofradías existentes eran las siguientes: Cofradía de Ánimas 43 ,}

con la aprobación del obispo D. Manuel Pérez Minayo en primero de 1779. La mayor parte de sus rentas están en la Real Caja del Crédito Públicc, por lo que no se curan hace años los enfermos ni se cumple la voluntad de la fundadora. Hay una iglesia con sacramento y en ella se ejercitan los hermanos de la Escuela de Cristo y la Congregación de hermanos de la Escuela de Maria, es su administrador actual y patrono D. Martín de Sesmaw. Idem, f. 164 v.

38 "En la calle de San Ildefonso hay un hospital, cuyo instituto es asistir en su convalecencia a los pobres que se curan en el Hospital de Santiago y en esto se invierten sus rentas según informó su mayordomo $D$. Gabriel Jiménez y en dotar con lo sobrante a pobres huértanos. Tiene su iglesia bien asistida de ropa y además necesario a la celebración del Santo Sacrificio de la Misa. El mayordomo capellán y demás oficiales según su fundación deben nombrarse todos los años con la asistencia del alcalde primero de esta villa". Idem, f. $164 \mathrm{v}$.

39 "Convento de la Encarnación y Mina, contiguo a la población. Tiene una iglesia muy hermosa y capaz, aunque poco adornada por la destrucción que en ella hicieron las tropas francesas». Idem, f. $163 \mathrm{v}$.

40 "Convento de San Francisco o San Benito. Los franceses destrozaron el convento de San Francisco que estaba extramuros de esta villa y a corta distancia de la población. Por porpia voluntad se trasladaron a la enfermeria que está en el arrabal de esta población. Su iglesia es muy pequeña e incapaz de reunir los fieles que concurren a las fiestas que en ellas se celebran pero traban con celo en la administración del santo sacramento de la penitencia».

41 "Convento de San Onofre. A dos leguas de distancia de esta villa hay un convento de reiigiosos descalzos. Administran los santos sacramentos a los moradores del arrabal de la Lapa, que así se denomina el terreno donde está situado".

42 Idem, f. 119-120.

43 "La Cofradía de Ánimas se gobierna por dos mayordomos del cuerpo del cabildo que nombra el Duque y de cuatro capellanes que bajo la dirección de los mayordomos piden para sufragio a las Ánimas y las Limosnas que juntan las entregan a éstos. Los mayordomos sirven gratis y los capellanes perciben anualmente 286 rs. cada uno por su trabajo y además la cuarta parte de 1.190 rs. para misas de Alba a razón de 6 rs. cada uno"s. 
del Santísimo Sacramento 44 , de la Santa Caridad 45 , de la Misericordia 46 y la Hermandad de San Pedro 47. En lo que respecta a capellanías, patronatos y memorias de misas, en el presente arreglo parroquial se efectúa una relación detallada de las mismas. En ellas se menciona al fundador o fundadora, al capellán encargado de celebrar las misas estipuladas, si se encontraban o no vacantes, por fallecimiento del antiguo poseedor, las cargas impuestas, es decir, el número de misas anuales convenidas por el fundador, las limosnas para cada misa en reales de vellón, las rentas globales, y por último las posesiones que pertenecian a cada una de ellas. En el informe se contabilizaban un total de 163 capellanías, una memoria de misa y 13 patronatos.

\begin{tabular}{|l|c|c|}
\hline Ingresos en censos y limosnas & $18.936 \mathrm{rs}$. & $13 \mathrm{mr}$. \\
\hline Distribución & $9.418 \mathrm{rs}$. & \\
\hline Restan & $9.518 \mathrm{rs}$. & $13 \mathrm{mr}$. \\
\hline
\end{tabular}

44 «Ésta existía en esta iglesia desde tiempo inmemorial y sin constituciones aprobadas hasta que con fecha 18 de diciembre de 1768 se formaron unas que aprobó el obispo $D$. Manuel Pérez Minayo por su auto de 2 de enero de 1769 bajo las cuales se rige y gobierna dicha cofradía, debe componerse de un mayordomo del cuerpo del cabildo por nombramiento de éste, de otro seglar y de 48 cofrades seglares de los de la primera distinción del pueblo y de 24 eclesiásticos seculares".

\begin{tabular}{|l|c|c|}
\hline Ingreso de rentas & $15.935 \mathrm{rs}$. & \\
\hline Descuento & $12.992 \mathrm{rs}$ & $23 \mathrm{mr}$. \\
\hline Resulta sobrante & $2.942 \mathrm{rs}$. & $23 \mathrm{mr}$. \\
\hline
\end{tabular}

45 "El Duque de Medinaceli nombra todos los años por derecho de patronato, el hermano mayor de la cofradía de la Santa Caridad, capellán y seis vocales que denominan seises. Su instituto es asistir con médico y medicinas a aquellos pobres jornaleros, que no están en el hospital de Santiago. Dar limosnas de pan a pobres, huéranos y viudas todos los domingos. Nombrar varios dotes para doncellas de esta población que cobran cuando toman estado. Hace años que no se da la limosna de pan, ni cobran los dotes. El actual hermano mayor es D. Manuel Espalzan. Idem, f. 164 v.

46 "Se compone esta cofradía de 30 hermanos, quince eclesiásticos, quince seglares. Está erigida en virtud de Breve y aprobadas sus constituciones por el obispo D. Amador Merino Malaguilla en junio de 1738. Es su regente $D$. Domingo Gómez y su instituto la asistencia a los pobres enfermos vergonzantes, que no tienen la de los hospitales y caridad. No tienen rentas ni se hacen petitorios con consideración a la calamidad de los tiempos. El regente y seis consiliarios debe nombrarse todos los años por los hermanos". Idem, f. 165.

47 "Tiene asignación a la iglesia Colegial y parroquial de esta villa. Se compone de 21 sacerdotes. No tiene rentas ni obención alguna. Muy pobre. Los hermanos de San Pedro son los únicos que administran el Sacramento de la Penitencia a los fieles de esta parroquia, los que auxilian a los moribundos y enseñan la doctrina cristiana al pueblo sin que por este trabajo se les contribuya con limosna algunam. Idem, f. 162. 
Una vez fundada la capellanía, se le cedía a un capellán su administración. En la relación estudiada se observa que 38 capellanías se hallaban vacantes por muerte de su último poseedor y una por secularización. Tan sólo el $6 \%$ de las capellanías estaban regidas por el colector de Zafra junto a los trece patronatos, el resto, es decir, el $94 \%$ eran vecinos de otras localidades. En la jurisdicción del obispado de Badajoz se repartían de la siguiente manera: cuatro presbíteros y un diácono de la capital poseían un total de 39 capellanías, un presbítero de Villagarcía 19, uno de Oliva 5, uno de Jerez 3 y un clérigo de menores de Almendral otras 3. Otros poseedores eran vecinos de poblaciones de territorios de la Orden Militar de Santiago: Los Santos de Maimona, Fuente de Cantos y Villafranca de los Barros. También había capellanes que vivían en poblaciones andaluzas: Sevilla, Cádiz, Aracena, Torredonjimeno (Jaen), y hasta en Madrid un clérigo de menores.

El número de misas establecidas anualmente varíaban entre 2 y 34 , aunque debo hacer la salvedad que en algunas de ellas no se especificaba cantidad alguna. Las limosnas -en reales de vellón- para sufragar los gastos de cada celebración oscilaban entre 3 y 18, siendo el promedio más generalizado el de 9 reales por misa. En cuanto a las rentas globales se aprecia una gran oscilación. La capellanía de renta más baja contabilizada era de 15 reales, pertenecía a una de las 5 capellanías que poseía el presbítero D. Cayetano Alcor Cumplido, vecino de la villa de Torredonjimeno. Y la de renta más alta era de 1.938 reales anuales, que correspondía al presbítero de los Santos de Maimona D. Francisco Carvajal. Sin embargo, la cantidad más generalizada estaba comprendida entre 50 y 400 reales.

Al ser las capellanías fundaciones perpetuas por las que una persona segregaba de su patrimonio ciertos bienes (en vida o por testamento) y formaba con ello un vínculo, es decir, un todo indivisible, destinado a la manutención o congrua sustentación de un clérigo, que se obligaba por ello a celebrar un cierto número de misas por el alma del fundador, se observa en la relación que estoy comentando que las casas eran los bienes inmuebles que mayor porcentaje suponían (36\%), seguidos de suertes de tierra $(25 \%)$, cercados $(7,5 \%)$, olivares $(6,5 \%)$, viñas $(5,5 \%)$, huertas $(4,5 \%)$, molinos harineros, chaparrales y censos $(1,5 \%)$ respectivamente. Por último un $8 \%$ tenían sus posesiones en el Crédito Público y un $2,5 \%$ en la Real Hacienda.

Siguiendo esta misma línea y como complemento de la información descrita, debo decir que los datos aportados en la visita pastoral -que ini- 
ció en Zafra el 8 de mayo de 1832 el canónigo de la catedral y visitador general de la diócesis D. Marcelino Navarro- varían mucho con respecto a los expuestos anteriormente. En concreto se contabilizaban por un lado 210 capellanías, además de tres patronatos en la iglesia Colegial, doce patronatos administrados por el colector de perpetuas, 21 cuyos poseedores eran vecinos de esta villa y otros 23 patronatos cuyos capellanes eran vecinos de otras poblaciones 48 .

La Colegial de la villa de Zafra, según las bulas de erección y concordia debería componerse de 4 dignidades: un abad mitrado con jurisdicción ordinaria sobre todos los miembros del cabildo, un arcediano con el título de Feria, una cantoría y una tesorería. Además 12 canonjías, entre ellas una magistral y otra doctoral, que se proveían por oposición; 8 racioneros y 8 capellanes de coro. Pero en el momento de efectuarse este arreglo beneficial sólo residian en la Colegiata cinco canonjías entre ellas la doctoral, dos de sus poseedores estaban imposibilitados para asistir a la iglesia y cinco raciones. Todas eran de presentación del Duque de Medinaceli y Feria, excepto la doctoral y magistral que se elegia por el cabildo a pluralidad de estos y por oposición, mientras el Duque les daba el título. También había seis capellanías de coro perpetua, que presentaba libremente el Duque, mientras que las colaciones a todas ellas las realizaba el obispo de Badajoz. Sin embargo, la canonjía magistral -que por incongrua como todas las demás no fue convocada a oposición por el cabildo-, una ración y una capellanía estaban provistas por el patrono, pero sobre las cuales no se había producido la colación correspondiente, por haberse negado a la misma el obispo de Badajoz, fundando su oposición en que si no podían mantenerse los pocos individuos que quedaban en la Colegiata, menos podrían subsistir si estuvieran completas todas las plazas 49 .

Igualmente el Duque nombraba a las personas que servían las mayordomías de la mesa capitular, fábrica y ánimas del purgatorio, y la de los ministros y personas dependientes de esa Colegial (sacristán mayor, maestro de ceremonias, maestro de capilla, sochantre, organista, bajonista, pertiguero, candelario y campanero). Por el obispo eran nombrados los dos sacristanes menores, y por el cabildo seis cantores, cuatro mozos de coro, cuatro monaguillos y el ministral del órgano 50.

48 AAMB, Badajoz, Mitra, Actas de Santa Visita, leg. 15, n.? 39.

49 AAMB, Badajoz, Zatra, leg. 89, n. $3.158-f$, f. 5 v.

50 Como complemento de este apartado expongo una lista detallada del último personal de la Colegiata, con la fecha en que vacaron cada uno de sus cargos. Abad: D. José Martínez Torres, 
Al crearse la Colegial, la dotación patronal de los Duques de Feria se hizo efectiva con las rentas de una serie de predios rústicos en Zafra, Solana de los Barros, Villalba de los Barros y Santa Marta, que pasaron a ser considerados como propiedades del cabildo, parte de los cuales se destinaban a la fábrica de la iglesia, otra a beneficios y al sostenimiento de la fundación y capilla de los Suárez de Figueroa en la Colegiata ${ }^{51}$. La prodigalidad de la nobleza castellana con relación a la Iglesia debió ser notable durante toda la Edad Moderna. Así se vieron dotadas iglesias, parroquias, capillas y conventos con tierras, dehesas o pequeños predios que se desvincularon del propio señorío para amortizarse en estas fundaciones; además se cargaron sobre ellas censos 52 o foros que encarecie-

muerto el 24 de agosto de 1813.- Arcediano de Feria: D. Francisco Arnates, muerto el 8 de julio de 1803.- Chantre: D. Mateo Martínez del Río, muerto el 5 de enero de 1810.- Tesorero: D. Glas Jernónimo de Torrecilla, muerto el 22 de enero de 1800.- Doctoral: D. Domingo de Alonso Bernal, muerto el 30 de enero de 1817.- Magistral: D. Juan Hilario Martínez, el 7 de noviembre de 1811.- Canónigos: D. Diego Jesús Lobato, muerto el 20 de enero de 1801. D. Antonio Áivarez Guerra, muerto el 13 de junio de 1804. D. Juan José Ortega, muerto el 2 de agosto de 1806. D. José Venero, muerto el 3 de agosto de 1803. D. Juan Moreno Galeas, muerto el 24 de enero de 1813. D. José Gómez Cano, muerto el 21 de octubre de 1830. D. Leonardo de Leria, muerto el 12 de febrero de 1835. D. Francisco Álvarez Guerra, muerto el 11 de junio de 1843. D. Juan Gutiérrez, renunció el 1800.- Racioneros: D. Andrés Fernández, muerto el 19 de diciembre de 1800. D. Manuel Barroso, muerto el 24 de agosto de 1820. D. Juan Roncal, muerto el 27 de marzo de 1837. D. Tomás Miguel de Vidaurreta, muerto el 6 de febrero de 1820. D. José Castañón, muerto el 1 de mayo de 1837. D. José Álvarez Guerra, renunció el año 1813. D. Leonardo de Leria, ascendió en 1833.- Capellanes: D. Roque de la Paz, murió el 21 de abril de 1811. D. Lorenzo Zamora, muerto el 5 de junio de 1828.D. Juan Ramírez, muerto el 25 de enero de 1830.D. Marcelino Moreno López, muerto el 30 de septiembre de 1831. D. Rafael Rubio, muerto el 10 de noviembre de 1831. D. Tomás Martínez, muerto el 5 de junio de 1846. D. Antonio Martínez de la Cámara, muerto el 7 de abril de 1821. D. Manuel A. Martínez, ascendió el 13 de septiembre de 1833. VIvAs TABERo, Manuel, o. c. pp. 280-282.

51 Predios rústicos: Un cercado llamado "El Concejal», en Zafra, con 6 fanegas de extensión. Otro cercado llamado «El Gitano», en Zafra, con 6 fanegas de extensión. Cortinal calle del Almendro, en Zafra, con 6 fanegas de extensión. Una tierra montuosa y de mala calidad, en Solana, con 400 fanegas de extensión. Una tierra de baja calidad en Villalba, con 200 fanegas de extensión. Un olivar en Villalba, con 400 fanegas de extensión. Viñas y olivares en Santa Marta, con 300 fanegas de extensión. Aparte de estas fincas, de calidad muy mediana y de escasos frutos, el Duque donó al cabildo dos molinos harirneros en el término de Villaba de los barros, que por gozar de monopolio señorial, produjeron año tras año una excelente rentabilidad a la Colegial. Estas propiedades no eran las únicas que gozaba la Mesa Capitular, ya que a lo largo de 200 años, desde la fecha de su erección, había ido recibiendo donaciones destinadas al sostenimiento de capellanías, fundaciones $u$ obras pías que pasaban a su propio inventario. CARDALLIAguet Quirant, Marcelino, "Las rentas de la insigne iglesia Colegial de Zafra (Badajoz) a finales del Antiguo Régimen", REE, XXXVIII, III, 1982, pp. 477-499, especialmente en p. 479.

52 Contrato por el cual se sujeta un inmueble al pago de una pensión anual, como interés de un capital recibido en dinero y reconocimiento de un dominio que no se transmite con el inmueble. 
ron notablemente su rendimiento económico. Concretamente los Duques de Medinaceli tenían empeñado un capital que ascendía a 2.011.821 reales de vellón en censos perpetuos 53 , que disfrutaban varios conventos, hospitales, capellanías, fundaciones pías, cofradias, etc. por los cuales debían satisfacer unos intereses anuales de 60.353 reales de vellón y 19 maravedís. Sin contar con los 9.153 reales y 6 maravedís destinados a la fábrica de la iglesia Colegial, a la mayordomia de la Cofradía del Santísimo y al sostenimiento de su propia capilla. A este respecto el Duque más magnánimo debió ser el citado $\mathrm{D}$. Gómez Suárez, ya que en el transcurso de su existencia (1587-1635) es cuando se dotaron la inmensa mayoría de los censos y donaciones.

Muchos de los patronatos que se fundaron a finales del siglo $X V I$ y en el XVII, quedaron ya inscritos como propiedades del Cabildo al desaparecer sus titulares, y otros eran aplicados a misas y aniversarios que no llegaban a absorber la totalidad de su renta. Las escrituras de censos redimibles -que podían librarse de la obligación- también representaban un abultado capítulo de ingresos para las iglesias, ya que las permitían percibir anualmente numerosas cantidades por los réditos de los capitales censados de pequeños campesinos, propietarios de casas de habitación, hortelanos, etc., quienes a su vez veían escrituradas estas pequeñas propiedades y asegurada jurídicamente su disfrute y transmisión. Los diezmos, primicias y terrazgo del señorío de Feria y marquesado de Villalba pertenecían a los Duques; la Colegiata sólo percibía un noveno de estos diezmos, que se aplicaba al «beneficio curado y simple".

Por el «Plan summario de rentas annuas de la Insigne Iglesia Colegial de Zafra, de sus cargas distribuciones..." correspondiente al decenio 1786 a 1795 , se sabe que el total de sus rentas anuales ascendian a 107.944 reales de vellón y 4 maravedís 54 . Cuando en 1752 se pidió a la

53 Imposición hecha sobre bienes raices, en virtud de la cual queda obligado el comprador a pagar al vendedor cierta pensión cada año, contrayendo también la obligación de no poder enajenar la casa o heredad que con esta carga ha comprado, sin dar cuenta primero al señor del censo, para que use de una de las acciones que le competen, que son: o tomarlo por el tanto que otro diere, o percibir la veintena parte de todo el precio en que se ajustase.

54 Quedaban distribuidos de la siguiente forma:. Alquileres de casas en Zafra propiedad de la Capitular 21.582 rs. y $14 \mathrm{mrs}$.. Censos perpetuos, 8.726 rs. y $30 \mathrm{mrs}$. Beneficio curado y simple (1/9 de los diezmos) 13.865 rs. y 5 mrs.. Arriendo de las propiedades rurales de Zafra, 7.598 rs. y 5 mrs.. Hacienda en Villalba, Solana y Santa Marta de los Barros, 8.181 rs. y 33 mrs.. Molinos harineros en Villalba, 6.909 rs. y 10 mrs. Rentas de Aniversarios, del Santísimo y de la Capellanía de A. Martín Gordillo, 1.455 rs.. Rentas sobrantes de la hacienda del Santísimo, 
Colegial que hiciese una declaración pormenorizada de sus propiedades y rentas para el establecimiento de la "única contribución", fueron inventariadas todas las casas y solares que poseía el cabildo dentro del casco urbano de Zafra y en los pueblos inmediatos. Veinte años más tarde, en 1771, la administración volvió a pedir a la Mesa Capitular que declarase de nuevo cómo habían variado aquellos inventarios, el resultado fue un notable incremento de los bienes inmuebles poseídos por la iglesia, además de un aumento paralelo de los censos redimibles que se percibian anualmente, ya que las casas que figuraban en el inventario de 1771 como: "bienes de la Mesa Capitular que han pasado a otros sujetos" dejaron de pagar los correspondientes arrendamientos y se dieron a censo por cantidades ligeramente inferiores, mientras la Colegiata adquiría otras 15 fincas urbanas que, a su vez, arrendaba.

La política fiscal de Carlos III y de sus ministros «ilustrados» incidió de manera directa en las rentas y beneficios eclesiásticos sobre todo a partir de las guerras contra Inglaterra de 1762 y 1780 , pues la emisión continua de "vales reales" fue deteriorando la estabilidad monetaria del reino, con una continua inflación y el persistente déficit presupuestario de la Corona. El 1793 se renovó por Carta Circular de 20 de febrero, las medidas ya adoptadas en 1780; es decir, obligar a la imposición de todos los capitales de capellanías, obras pías, fundaciones, etc, en "vales reales", cuyos réditos iban cargados a la Renta del Tabaco, con un interés del tres por ciento, medida que se incrementó durante el reinado de Carlos IV. Estas disposiciones y, sobre todo, las Reales Cédulas de 1803 y 1805 sobre desvinculación de mayorazgos, redención de censos y autorización de enajenar las propiedades amortizadas, con obligación de imponer la mayor parte del producto en la Caja de Amortización y Consolidación de Vales Reales, fueron aprovechadas por el Cabildo de Zafra -muy posiblemente obligado a ello- para vender un abultado lote de sus propiedades rústicas y urbanas -sobre todo estas últimas- en el transcurso de los años 1805, 1806 y 1807; de igual manera a como otras instituciones de caracter religioso perdieron en estos años gran parte de sus vinculaciones.

Por otra parte, la propia guerra contra la nación francesa incidió también en las propiedades de la Colegial, ya que 11 casas propiedad del cabildo fueron destruidas y arruinadas durante la contienda, y en consecuencia dejaron de percibir arriendos. Las Cortes de Cádiz, en su labor legislativa, suprimieron las rentas correspondientes a los molinos harineros de Villalba de los Barros, además de obligar al Cabildo a enajenar parte de su patrimonio para depositar el producto en la Junta Nacio- 
nal de Crédito Público. La restauración de Fernando VII en 1814 significó una recuperación de parte de lo perdido, sobre todo de las rentas de los molinos y obligó a los pueblos al pago de todos los derechos señoriales; pero la Colegiata no recuperó los capitales depositados en el Crédito Público, que el monarca decidió conservar por Real orden de 18 de mayo de 1814.

Pero cuando las rentas de la Mesa Capitular sufrieron una disminución realmente drástica fue durante el Trienio Liberal, iniciado en 1820 . En virtud de la Ley de 11 de octubre de este último año se suprimieron todos los mayorazgos, fideicomisos, patronatos y cualesquiera otra especie de vinculaciones, censos, foros, juros o de cualquier otra naturaleza. Quedaba prohibido fundar mayorazgos, patronatos, capellanías, obras pías, etc. y se ocupaba de las instituciones eclesiásticas incapacitándolas para la adquisición en lo sucesivo de bienes inmuebles o derechos sobre ellos. Aunque esta ley fuera anulada por Fernando VII el 11 de marzo de 1824 y se intentara devolver toda su fuerza económica al régimen señorial, el proceso iba siendo irreversible y en el caso de las instituciones eclesiásticas, los primeros pasos de la desamortización se dieron con firmeza contra ciertas fuentes de ingresos y rentas que fueron ya irrecuperables. En el estado de las rentas que tuvo la iglesia Colegial de Zafra, correspondiente al decenio de 1826 a 1835 se consignaron censos y capellanías, pero el resultado total de las cuentas quedó fuertemente menguado, oscilando unos años con otros entre los 51.413 rs. y 4 mrs. de 1826 y los 50.912 rs. y $11 \mathrm{mrs}$. de 1835, es decir, menos de la mitad de lo recaudado en $1818^{55}$.

A continuación me centro en el segundo bloque de este apartado, es decir los diezmos 56 y primicias 57 . Para abordar el estudio de estos as-

2.556 rs. y 14 mrs.. Misas y honras a cargo de la mayordomía de Ánimas, 1.901 rs.. Varios patronatos y capellanias, 1.761 rs. y 19 mrs.. Funciones y obvenciones eventuales y entierros del cabildo, 2.987 rs. Total de rentas anuales 107.944 rs. y $4 \mathrm{mrs}$.

55 Los capítulos en los que se repartía este ingreso eran:. Predios rústicos, 8.035 rs. y $8 \mathrm{mrs}$. Predios urbanos, 2.059 rs. y 13 rs. Censos en granos, 274 rs. Censos, 33.499 rs. y 26 mrs. Entierros, 700 rs. Beneficio curado, 997 rs. y 2 mrs. Diezmos, 5.847 rs. y 23 mrs.

56 Diezmos: prestación que los fieles pagaban a la Iglesia en frutos de la tierra, ganados y por otros conceptos, para atender a la subsistencia del culto y sus ministros. Generalmente consistía en la décima parte de los productos de ahi su nombre. Se dividian en espirituales (correspondian a los clérigos y demás ministros) y temporales (correspondian a los patronos laicos). Los espirituales podian ser: prediales (frutos de la tierra y sus heredades -mayores o menoresy rentas del trabajo personal), personales o mixtos.

57 Primicias: prestación de los primeros frutos y ganados que, junto con el diezmo, se daba a la Iglesias. 
pectos y como complemento a la información que nos proporciona el presente arreglo parroquial de la villa de Zafra, considero esencial la utilización de una documentación inédita que se encuentra en el Archivo del Arzobispado de Mérida-Badajoz, que proporciona multitud de detalles de los distintos pueblos de la diócesis. La documentación en concreto consiste en unas informaciones que solicitó la Comisión de Diezmos, a través una circular expedida el 28 de septiembre de 1838, al gobierno eclesiástico de Badajoz, mediante la contestación a seis preguntas relacionadas con los diezmos y primicias 58 . Para ello el gobierno eclesiástico el 13 de octubre las remitió a los párrocos de la diócesis y éstos enviaron las correspondientes respuestas a las interrogantes planteadas. Por la declaración de D. Manuel Ángel Martínez del Río, juez pesquisidor de Zafra, se sabe que en el término de dicha villa se producía trigo, cebada, avena, habas, garbanzos y muy poco centeno. El olivo se fue extendiendo hacía años y por tanto la producción de aceite fue cada vez más abundante, caso contrario a las viñas de las que prácticamente no se recogía nada por esta fecha. El zumaque se criaba en los montes del arrabal de la Lapa 59. Había también huertas en las que se cultivaban hortalizas, legumbres y frutas. Al ser un territorio pequeño en extensión, era también muy poco el ganado que se criaba y alimentaba en él. No obstante había ganado lanar, caprino, vacuno, caballar y de cerda. Todos los frutos y semillas estaban sujetos a la exacción decimal como también a la primicia si llegaba a 12 el número de fanegas que recogía el labrador. El aceite no estaba sujeto a primicia ni se diezmaba. El dueño recogía su aceituna y la llevaba al lagar y según

58 1.) Qué clases de frutos producen las tierras, con distinción de mayores y menores y expresión nominal de cada uno, y que especies de ganados se crían y mantienen en ellas. 2.a) Cúales de aquellas y éstos se hallan sujetos a la exarción decimal y quales no lo están determinando las especies, como también los que lo estén a las primicias en qué término. 3.9) Qué cuota se exige por especie en razón de diezmo, es decir, si la 8. $10.2,20.7$ parte, expresando las causas de las diferencias. 4.? $)$ Qué usos y costumbres hay para verificar la exacción decimal, bajo que medida y en qué términos se realiza con respecto a cada una dé las especies de frutos y animales en que no haya uniformidad. 5.") Si dicha exacción decimal se ejecuta sobre la masa total de la cosecha o si se hacen antes algunas deducciones y por qué causa. 6.") En cuanto al diezmo de los ganados y demás animales, que costumbre hay para graduar la exacción, si es por el valor que tienen, o por cabeza, y en qué proporción o número de éstas. AAMB, Badajoz, Decimal, leg. 1, n. ${ }^{\circ} 13$.

59 Zumaque: vino de uva. Nombre vulgar de varias especies del género "Rhus", en la familia de las anardiaceas. En la flora mediterránea usado en las tenerias, es un arbusto de unos $3 \mathrm{~m}$ de alto; hojas de once a 15 toliolos, lanceolados, dentados, con flores primero blanquecinas y después encarnadas. Contiene mucho tanino por lo que se emplea como curtiente. Prospera en los terrenos calizos de los climas secos y es arbusto que vive y retoña muchos años. 
el número de arrobas que recogía pagaba su diezmo. La uva se cobraba regularmente en dinero, es decir, según el valor que tenía una carga común. Las huertas pagaban su diezmo por los frutos que en ellas se cultivaban. Siendo el diezmo según costumbre, la décima parte del arriendo que pagaba el hortelano al dueño de la huerta, cobrándolo en dinero. La cuota que se exigía era la décima, es decir, de diez una. Se rebajaba también un $10 \%$ al producto de la cosecha y del resultado se pagaba el diezmo. La costumbre que había en el pueblo para verificar la exacción decimal, era avisar al cogedor para que éste fuese a recoger el diezmo a las eras, o a las casas de los labradores, utilizando la medida establecida por él o por los agricultores. Para el aceite se desplazaban a los lagares. Los demás frutos como el zumaque se diezmaban por arrobas, es decir, de cada cien arrobas diez, que en Zafra se recaudaban en dinero, valorando cada arroba al precio al que se vendía aquel producto. La lana se diezmaba en especie, es decir, por vellones -toda la lana de una res que esquilada salía junta-, o arrobas, y también se cobraba por décima. En Zafra no había habido nunca costumbre de realizar alguna deducción para el pago del diezmo, ya que éste se ejecutaba sobre el total de la masa o cosecha recogida. Sólo se había efectuado la del $10 \%$ en granos con respecto a las granzas o residuos que quedaban de los cereales y otras semillas cuando se acribaban. Con respecto a los ganados se seguía la misma tradición, de cada diez cabezas una 60 .

Hecho este inciso debo decir que a la Colegiata, por medio de la bula de erección, se le agregaron todos los diezmos y derechos que pertenecían al curato, dando facultad al abad para nombrar a un canónigo que se encargase de su servicio, y a éste le daba también potestad para que nombrase dos racioneros coadjutores que le ayudasen en la administración de los sacramentos. Por ello la iglesia Colegial percibía todo lo perteneciente al curato, a excepción de los derechos de bautismos y casamientos que correspondían a los curas y los entierros a los capellanes.

Aunque para el presente arreglo parroquial se tomó de referencia los diezmos y primicias producidos en Zafra entre 1814-1818, me parece interesante insertar anteriormente los correspondientes al quinquenio de 1803-1807, para de esta forma poder apreciar la evolución producida sobre estos conceptos.

60 AAMB, Badajoz, Decimal, leg. $1, n .^{\circ} 13$, f. 1-3. 
Diezmos, gruesa y demás derechos del quinquenio 1803-1808 61

\begin{tabular}{|c|c|c|c|c|c|c|c|c|c|}
\hline Años & \multicolumn{3}{|c|}{ Trigo } & \multicolumn{3}{|c|}{ Cobada } & \multicolumn{3}{|c|}{ Centeno } \\
\hline & FANEGAS & CELEMINES & CLARTILOS & FANEGAS & CELEMINES & CUARTILOS & FANEGAS & CELEMINES & CUARTILOS \\
\hline 1803 & 77 & 7 & & 74 & 8 & & 4 & 6 & 2 \\
\hline 1804 & 61 & 1 & $3 / 4$ & 76 & 9 & & 4 & 7 & 2 \\
\hline 1805 & 93 & 6 & 2 & 97 & 6 & & 5 & 4 & \\
\hline 1806 & 151 & 2 & 3 & $1 \overline{14}$ & 5 & & 10 & 9 & 2 \\
\hline 1807 & 125 & 3 & 2 & 109 & 8 & 3 & 22 & 5 & \\
\hline Total & 508 & 9 & 2 & 473 & & & 47 & 8 & \\
\hline
\end{tabular}

La producción total en cuanto a diezmos, gruesa 62 y demás derechos de este quinquenio fue de: 508 fanegas, 9 celemines y dos cuartillos de trigo; 473 fanegas de cebada y 47 fanegas, 8 celemines de centeno ${ }^{63}$. Estos granos se repartían en 31 partes entre 10 prebendados (cinco canónigos y cinco racioneros), y seis capellanes de coro ${ }^{64}$. Si todas las plazas de que constaba el cabildo hubiesen estado cubiertas y los repartimientos se hubieran hecho con arreglo a las 80 partes que señalaba la bula de erección, la asignación hubiese quedado establecida de la siguiente manera:

\begin{tabular}{|c|c|c|c|c|c|c|c|c|c|}
\hline Asignación 65 & \multicolumn{3}{|c|}{ Trigo } & \multicolumn{3}{|c|}{ Cebada } & \multicolumn{3}{|c|}{ Avena } \\
\hline & FANEGAS & CELEMINES & CLAATTLLOS & FANEGAS & CELEMINES & CUARTILOS & FANEGAS & CELEMINES & CUARTILOS \\
\hline Al abad por ocho partes & 10 & 2 & & 9 & 4 & & & 10 & \\
\hline $\begin{array}{l}\text { A las otras tres } \\
\text { dignidades por } 4\end{array}$ & 5 & 1 & & 4 & 8 & & & 5 & \\
\hline $\begin{array}{l}\text { A cada uno de los } 12 \\
\text { canónigos per } 3\end{array}$ & 3 & 9 & & 3 & 3 & 6 & & 3 & 3 \\
\hline $\begin{array}{l}\text { A cada uno de los } 8 \\
\text { racioneros por } 2\end{array}$ & 2 & 6 & 2 & 2 & 4 & & & 2 & 2 \\
\hline $\begin{array}{l}\text { A cada uno de los } 8 \\
\text { capellanes por } 1\end{array}$ & 1 & 3 & 1 & 1 & 2 & & & 1 & 1 \\
\hline Sobran & & 1 & & 1 & 3 & 1 & & 11 & 1 \\
\hline
\end{tabular}

Basándome en los datos que aporta el presente reglamento parroquial se puede afirmar que en el quinquenio 1814-1818 la producción total de

61 AAMB, Zafra, leg. 89, n.? 3.158 f, f. 6-11

62 Gruesa: en los cabildos y capítulos eclesiásticos, renta principal de cualquiè prebenda en que no se incluyen las distribuciones.

63 Por término medio correspondían a cada año del quinquenio: 101 fanegas, 9 celemines de trigo, sobrando 2/4; de cebada 94 fanegas, 7 celemines y un cuartillo, y de avena 9 fanegas, 3 celemines y un cuartillo.

64 Según la repartición le tocaba a cada prebendado: 8 fanegas, 2 celemines y 2 cuartillos de trigo; 7 fanegas, 2 celemines y 2 cuartillos de cebada y 9 celemines de avena. A cada capellán 3 fanegas, 3 celemines y un cuartillo de trigo, sobrando 1 celemin; 3 tanegas, 2 cuartillos de cebada y sobra un celemín; y 3 celemines y 2 cuartillos de avena, sobrando un cuartillo.

65 AAMB, Zafra, leg. 89, n. ${ }^{9} 3.158-f$, f. $6 \mathrm{v}$. 
Zafra aumentó considerablemente en las partidas de trigo y cebada. EI cómputo global quedó establecido así: 1.016 fanegas y 9 celemines de trigo; 909 fanegas y 6 celemines de cebada; 289 fanegas y 6 celemines de avena, todo esto en lo concerniente a diezmos. El resultado en cuanto a primicias fue de: 235 fanegas de trigo, 236 de cebada, 86 de avena, 58 de habas, 31 de garbanzos y 19 de uvas. El diezmo de habas, garbanzos, junto con ganados y lana, comprendidos bajo el término de minucias, se arrendaban en pública subasta, valorándose en 22.000 reales de vellón. El diezmo de aceite se recaudaba en especie, pudiendo graduarse su producto en el citado quinquenio en 15.000 reales de vellón. El deán y cabildo de la catedral de Badajoz era el administrador de los diezmos y primicias de Zafra y del diezmatorio común del obispado.

El cogedor de todos los diezmos de esta villa era el presbítero D. Juan Moreno Cordero, nombrado por el obispo, excepto para el aceite que era el deán, quien percibía por su trabajo un $8 \%$ de los granos y semillas que recogia y 8 maravedís por fanega para paneras en que depositarlos y media décima por el diezmo de aceite 66 . El juez pesquisidor era el presbítero D. Manuel Ángel Martínez del Río, nombrado por el deán del cabildo y percibia por su trabajo el $2 \%$ del diezmo de granos y uvas.

Las primicias pertenecían al deán y cabildo de la catedral de Badajoz. De los diezmos, la fábrica de dicha catedral percibia por la segunda casa excusada 31 fanegas y 6 celemines de trigo, 66 de cebada, 7 de avena y 3 de garbanzos 67 . El diezmo de exentos ascendía a 23 fanegas y 6 celemines de trigo, 20 fanegas y 6 celemines de cebada, 2 fanegas de avena, 16 de habas y 5 tanegas y 5 celemines de garbanzos 68 . Los diezmos restantes se distribuian de la siguiente manera: del acervo común se sacaban 40 fanegas de trigo y 20 de cebada para el beneficio curado de Zafra;

66 Troje, granero, silo donde se guardaba el trigo, el pan o la harina.

67 El excusado se llamaba así porque a un contribuyente determinado se le excusaba de pagarlo a la Iglesia, debiéndolo hacer a la Corona, su hogar recibía el nombre de casa excusada.

68 La Real Cédula de 8-VI-1796, en aplicación de un Breve de 8 de enero del mismo año, abolió todas las exenciones concedidas por privilegio (general y especial) o costumbre, menos la parte correspondiente a los beneficios curados y a las fábricas de iglesia, ordenando que se pagasen a quienes legítimamente pertenecían, y otra de 19 de agosto del mismo año, extendió esta abolición a las tercias reales. Por el capítulo 5.9 de la Pragmática de 30-VII-1800, que instituia la Comisión de Consolidación de Vales Reales, se aplicaron a la amortización de éstos sin excepción. Y por Real Cédula de 27-XII-1802 se confió a dicha comisión, que actuaba bajo la autoridad del Consejo de Hacienda, el conocimiento de las causas relativas a los diezmos. GrEGoRIO DE TEJADA, Manuel Teruel, Vocabulario básico de la historia de la lglesia, Crítica, Barcelona 1993, pp. 151-152. 
después el Real noveno decimal y lo demás se repartía en nueve novenos, de los cuales dos percibía el Marqués de la Lapilla por "tercias reales" y de ella salía el Tercio Real, uno y medio el obispo, tres el deán y cabildo de la catedral, medio el beneficio curado de Zafra, otro medio el beneficio simple, otro medio el Arcipreste de la Parra y uno la Iglesia Colegial 69 .

\begin{tabular}{|c|c|c|c|c|c|c|}
\hline Recaudación ${ }^{70}$ & $\begin{array}{r}\text { Trigo } \\
\text { tan./cel. }\end{array}$ & $\begin{array}{l}\text { Cebada } \\
\text { fan./cel. }\end{array}$ & $\begin{array}{r}\text { Avena } \\
\tan / \text { cel. }\end{array}$ & $\begin{array}{l}\text { Habas } \\
\text { tan./cel. }\end{array}$ & $\begin{array}{r}\text { Garbanzos } \\
\tan / \text { cel. }\end{array}$ & $\begin{array}{r}\text { Uvas } \\
\text { reales }\end{array}$ \\
\hline Diezmos & $961 / 9$ & 823 & $280 / 6$ & & & \\
\hline Primicias & 235 & 236 & 86 & 58 & 31 & 1.938 \\
\hline Casa excusada & $31 / 6$ & 66 & 7 & & 3 & \\
\hline Diezmos de exentos & $23 / 6$ & $20 / 6$ & 2 & 16 & $5 / 5$ & \\
\hline Total & $1.251 / 9$ & $1.145 / 6$ & $375 / 6$ & 74 & $39 / 5$ & 1.938 \\
\hline Distribución & $\begin{array}{r}\text { Trigo } \\
\text { tan.icel/cuar. }\end{array}$ & $\begin{array}{r}\text { Cebada } \\
\text { fan.cel//cuar. }\end{array}$ & $\begin{array}{r}\text { Avena } \\
\tan / \text { /col/cuar. }\end{array}$ & $\begin{array}{r}\text { Habas } \\
\tan . / c a l . / c u a r .\end{array}$ & $\begin{array}{l}\text { Garbanzos } \\
\tan / c e l . / c u a r .\end{array}$ & $\begin{array}{l}\text { Uvas } \\
\text { rs./mrs. }\end{array}$ \\
\hline Real noveno decimal & $86 / 3 / 1$ & $74 / 6 / 3$ & $26 / 6$ & & & $112 / 1$ \\
\hline Tercio Real & $62 / 1 / 1$ & $53 / 7 / 3$ & $18 / 1$ & & & $80 / 22$ \\
\hline Óbispo & $124 / 3$ & $107 / 4 / 3$ & $38 / 2$ & & & $161 / 12$ \\
\hline Cabildo de Badajoz & $444 / 2 / 3$ & $414 / 8$ & $157 / 8 / 2$ & $54 / 1 / 3$ & $31 / 9$ & \\
\hline $\begin{array}{l}\text { Fábrica Caledral } \\
\text { de Badajoz }\end{array}$ & $31 / 6$ & 66 & 7 & & 3 & \\
\hline $\begin{array}{l}\text { Curato y beneficio } \\
\text { de Zafra }\end{array}$ & $122 / 10$ & $71 / 7$ & $25 / 5 / 3$ & & & $107 / 19$ \\
\hline Fábrica de su iglesia & $82 / 10$ & $71 / 7$ & $25 / 5 / 3$ & & & $107 / 18$ \\
\hline $\begin{array}{l}\text { Sacristanes de } \\
\text { su iglesia }\end{array}$ & 24 & & & & & \\
\hline Arcipreste de la Parra & $41 / 5$ & $35 / 9 / 2$ & $12 / 8 / 3$ & & & $53 / 26$ \\
\hline Marqués de la Lapilla & $110 / 5 / 1$ & $95 / 5 / 2$ & $33 / 11$ & & & $143 / 14$ \\
\hline $\begin{array}{l}\text { Pesquisidor de la } \\
\text { rastra (mieses) }\end{array}$ & $13 / 4 / 2$ & $13 / 1 / 2$ & $4 / 1 / 3$ & & & \\
\hline Cogedor de diezmos & $84 / 11 / 3$ & $121 / 2$ & $24 / 4 / 3$ & $3 / 10 / 1$ & $2 / 3$ & $193 / 27$ \\
\hline Diezmos de exentos & $23 / 6$ & $20 / 6$ & 2 & 16 & $5 / 5$ & \\
\hline Totales & $1.251 / 9$ & $1.145 / 6$ & $375 / 6$ & 74 & $39 / 5$ & 1.938 \\
\hline
\end{tabular}

69 La primera concesión directa al rey fue hecha "ad triennium» el 5-IV-1247, para sufragar los gastos de la conquista de Sevilla, habiendo constancia de las prórrogas de 1265, 1275 y 1302. Se trataba pues de un subsidio de cruzada consistente en la tercera parte de los diezmos, o lo que es lo mismo, dos terceras partes de un tercio de la masa decimal, que cuando se contabilizaron recibieron el nombre de "tercias reales", que a veces la Corona enajenaba, en todo o en parte, en favor de terceros (señores, monasterios, etc.). La participación en los diezmos de acuerdo con las constituciones sinodales, dio lugar a las llamadas uvisitas de terciam.

70 AAMB, Zafra, leg. 90, n. ${ }^{9} 3.161$, f. 129. Contaduría de la Catedral de Badajoz 
Aunque ya he comentado la evolución general de las rentas de la Colegial, me centraré ahora en la renta anual, cargas y obligaciones de la misma y en el repartimiento correspondiente asignado a cada uno de los miembros del cabildo, primero con los datos provenientes del quinquenio de 1803-1807 y por último con los del período comprendido entre 18141818, que establece el presente reglamento como referencia ineludible para poderse llevar a cabo la reforma beneficial mencionada. La renta anual del primer quinquenio ascendió a un total de 113.317 rs. y $23 \mathrm{mrs}$, de los cuales se dedujeron 91.630 rs. y 14 mrs. en concepto de las cargas y obligaciones que tenía que cumplir el cabildo, por lo que le quedaba a la iglesia un montante de 12.556 rs. y $1 / 5$ para gastos extraordinarios e imprevistos. Sobre este particular debo decir que las cargas y obligaciones que tenía el cabildo eran: ejercer la cura de almas y la administración de los sacramentos. Esto lo realizaba uno de sus canónigos, ayudado por 3 racioneros, bajo la aprobación del obispo. Percibian además de las rentas de sus respectivas prebendas el producto de los derechos y emolumentos provenientes de la administración de los sacramentos. El «lus sepelendi» lo ejercía el cabildo en los entierros de la mayor pompa y en los otros por medio de los capellanes de coro. También celebraban las misas mayores en los días de fiesta y todo lo correspondiente al culto público. Como cuerpo colegiado cantaba y rezaba diariamente en el coro las horas canónicas y además tenia que cumplir con las fundaciones particulares que poseía.

Sobre estos datos el cabildo de Zafra -en fecha 3 de septiembre de 1815- hizo una serie de apreciaciones. En principio afirmó, que no eran reales las rentas expresadas, aduciendo unas notas aclaratorias al respecto ${ }^{71}$. Al mismo tiempo y en lo concerniente a cargas y obligaciones -continuó diciendo- no se incluían en esta partida el gasto de pontificales y medios pontificales en los días que la bula de erección le concedía al abad para que celebrase de esa manera. Tampoco el de misas de dignidad, ni el de vestuarios de canónigos, porque no había ni dinero ni individuos que pudieran celebrar estas funciones. Igualmente no se cumplían la mayor parte de las fundaciones de misas, maitines, ni aniversarios y otras obras pías, que componian la mayor parte del haber de

71 1.) La destrucción de predios rústicos y urbanos propios de esta iglesia por la invasión de los franceses. 2.9) La destrucción de otros sobre que estaba impuesto a censo, varios principales. 3.a) La decadencia que tiene la labor de que resulta mucho perjuicio en las rentas que anteriorrmente por las tierras. $4 .^{2}$ ) La falta de pago en los censualistas que aún conservaban fincas pero arruinados de resulta de los malos años, por último con las calamidades de la guerra. Sólo el Crédito Público y la Real Renta de Tabaco adeudaban ya a esta lglesia 307.743 rs. y 25 mrs. 
esta iglesia, porque sus partidas principales estaban unas en la Real Caja de Amortización y otras en la Renta del Tabaco. Sobre este particular, sólo se celebraban algunas que pertenecían a ciertas propiedades de la Colegial o las tenían en censo algunos particulares, observándose también un considerable retraso en su cobro, aunque esto era comprensible debido a las circunstancias nefastas del momento. De todo lo expuesto se deducía una gran decadencia en las celebraciones litúrgicas ya que no podían efectuarse con la solemnidad y el boato que años atrás se ejecutaban.

Por tanto teniendo en cuenta todo esto la distribución de las rentas que les correspondería a los distintos miembros del cabildo, si éstas fueran ciertas, sería la siguiente: al abad 6.525 rs. y $18 \mathrm{mrs}$., a cada una de las dignidades (arcediano, chantre, tesorero) 3.476 rs. y 26 mrs., a cada uno de los 12 canónigos 2.607 rs. y $31 \mathrm{mrs}$, a cada uno de los ocho racioneros 1.841 rs. y 30 mrs. y a cada uno de los ocho capellanes 1.215 rs. y 7 mrs.

En lo que respecta al quinquenio de 1814-1818, se observa un aumento de los ingresos anuales, ya que ascendieron a un total de 114.501 rs. y 23 mrs. A esta cantidad se le aplicó un descuento de 100.786 rs. y 2 mrs., resultando un saldo de 13.786 rs. y $21 \mathrm{mrs}$. Del cómputo global de rentas, se destinaron para la dotación de beneficio 73.701 rs. y 39 mrs.

Rentas aplicadas a la dotación de beneficios en reales y maravedíes

\begin{tabular}{|c|c|c|}
\hline${ }^{*}$ Rentas corrientes & $52.226 / 9$ & \\
\hline *Bajas & -7.18217 & \\
\hline Total & & 43.04326 \\
\hline * Rentas no corrientes & 7.80312 & \\
\hline${ }^{*}$ Bajas & -3.5446 & \\
\hline Total & & 4.2596 \\
\hline " Fondos en el Crédito Público & 35.67824 & \\
\hline * Bajas & -11.27917 & \\
\hline Total & & 24.3997 \\
\hline Suma total de rentas & & 73.70139 \\
\hline
\end{tabular}

El modo de repartir las rentas según disponía la bula de erección se mantuvo hasta que el cabildo el 16 de octubre de 1800 cambió esta orden mediante acta, efectuándose los repartimientos a partir de ese momento del siguiente modo: a los capellanes de coro se les asignó su parte según lo dispuesto por la bula, como se hacía anteriormente y lo 
restante se distribuia en partes iguales entre el abad, dignidades, canónigos y racioneros. A este método se opusieron algunos canónigos y entablaron el correspondiente recurso, por el despojo que se les hacía ante el obispo de Badajoz y su provisor, pero esta instancia no prosperó al morir casi todos los que reclamaron y por las calamidades que padeció España ante la invasión francesa. Las secuelas de la guerra se dejaron sentir gravemente en la Colegial, padeciendo por ello esta iglesia una gran miseria.

Las limosnas de 8 reales por cada una de las misas cantadas no iba ajustada como renta para congrua en el haber de las prebendas, por tanto, el individuo que no la podía celebrar, por imposibilidad física 0 moral, tenía que cederla íntegramente a otro para que la desempeñase. Esto mismo se hacia extensible a las misas de hora fija. Los vestuarios 72 de todas las misas cantadas por el cabildo, era costumbre que los hiciesen los racioneros y por ello percibían anualmente 193 rs. y $25 \mathrm{mrs}$. de vellón, pero habiendo solicitado éstos al obispo D. Gabriel Álvarez de Faria que los exonerase de esta carga, el prelado accedió a ello y los capellanes de coro aceptaron en tomarla y por tanto percibian la expresada renta anualmente aumentando sus beneficios y disminuyendo en contrapartida el de los racioneros ${ }^{73}$. La distribución en este arreglo parroquial se hizo de dos formas diferentes: la primera teniendo en cuenta lo dispuesto en la mencionada bula, y la segunda efectuada según las rentas y los beneficios producidos en la actualidad. Se completaba con observaciones sobre los inconvenientes o perjuicios que resultaban en sus comparaciones.

Distribución para cada uno de los beneficios según la Bula de erección en reales y maravedies ${ }^{74}$

\begin{tabular}{|l|r|}
\hline A la dignidad abacia & $6.495 / 8$ \\
\hline A las tres dignidades a 3.314 rs. y $18 \mathrm{mrs}$. cada una & $9.943 / 20$ \\
\hline A las doce canonjías a 2.550 rs. y 13 mrs. cada una & $30.604 / 20$ \\
\hline A las ocho raciones a 1.783 rs. y 6 mrs. cada una & $14.265 / 14$ \\
\hline A las ocho capellanías a 1.549 rs. cada una & 12.392 \\
\hline Fracción de maravedís que no ha tenido cómoda aplicación & 1 \\
\hline
\end{tabular}

72 Renta que se da en las iglesias catedrales a los que tienen obligación de vestirse en las funciones de iglesia o coro.

73 AAMB, Badajoz, Zafra, leg. 90, n. ${ }^{9} 3.161$, f. 138-139.

74 AAMB, Zafra, leg. 90, n. ${ }^{\circ} 3.161-f$, f. 143 v. 
Distribución para cada beneficio según el cabildo en reales y maravedíes

\begin{tabular}{|l|c|}
\hline A la dignidad abacial & $2.684 / 14$ \\
\hline A cada una de las tres dignidades & $2.552 / 14$ \\
\hline A cada una de las doce canonjías & $2.550 / 14$ \\
\hline A cada una de las ocho raciones & $2.545 / 14$ \\
\hline A cada una de las ocho capellanias & 1.549 \\
\hline
\end{tabular}

Comparando los dos cuadros se observa que el abad salía perjudicado, correspondiéndole 3.810 rs. y 28 mrs. menos. Lo mismo le ocurría a las tres dignidades a las que se les adjudicaba un saldo negativo de 762 rs. y 8 mrs. Por el contrario cada una de las ocho raciones aumentaba su renta en 762 rs. y 8 mrs., en compensación por lo detraído a las cuatro dignidades. Los canónigos y capellanes de coro no salían afectados en este repartimiento por estar completo el número de dignidades, pero sí sería más o menos gravoso para los canónigos cuando faltaran algunos de sus miembros, como quedaba demostrado repartiendo la renta líquida entre los beneficiados existentes en el momento de efectuarse este plan -3 canónigos, 5 racioneros y 6 capellanes de coro-, primero según la bula de erección y segundo según los acuerdos del cabildo.

Repartimientos de 73.702 reales y 5 maravedis según lo dispositivo de la bula entre los beneficios existentes en el día en reales y maravedies ${ }^{75}$.

\begin{tabular}{|l|c|}
\hline Una de las tres canonjías & $7.389 / 11$ \\
\hline Una de las cinco raciones & $5.194 / 7$ \\
\hline Una de las seis capellanías & $3.244 / 7$ \\
\hline
\end{tabular}

La misma renta según acuerdo del cabiido en reales y maravedís

\begin{tabular}{|l|c|}
\hline Una de las tres canonjías & $6.017 / 14$ \\
\hline Una de las cinco raciones & $6.017 / 14$ \\
\hline Una de las seis capellanías & $3.244 / 7$ \\
\hline
\end{tabular}

En la comparación de ambos cuadros se observa que los canónigos son los perjudicados ahora, recibiendo de menos $1.371 \mathrm{rs}$. y $31 \mathrm{mrs}$. $Y$ que con la cantidad detraída se aumentaba cada una de las cinco raciones en 283 rs. y 7 mrs. A continuación en el mismo plan se detallaban lo que percibian en reales y maravedis de vellón algunos encargados del

75 AAMB, Zafra, leg. 90 , n. $3.161-f$, f. 144 
cabildo por su ministerio, al igual que el de los dependientes que servían en dicha iglesia.

\begin{tabular}{|l|r|}
\hline $\begin{array}{l}\text { Canónigo cura mayor y los dos racioneros coadjutores } \\
\text { percibian anualmente además de las rentas de sus prebendas, } \\
\text { cada uno } 802 \text { reales y } 5 \text { maravedís } 76\end{array}$ & $2.406 / 15$ \\
\hline Canónigo magistral & 215 \\
\hline Sacristán mayor 77 & $499 / 17$ \\
\hline Maestro de ceremonias 78 & 225 \\
\hline Maestro de capilla 79 & 3.004 \\
\hline Sochantre 80 & 2.605 \\
\hline Ayuda de sochantre & 1.116 \\
\hline Organista 81 & 3.965 \\
\hline Bajonista 82 & 1.509 \\
\hline
\end{tabular}

76 AAMB, Zafra, leg. 90, n. $9.161-f$, f. 144-149)

77 El sacristán mayor lo es por nombramiento del Duque de Medinaceli. Sus obligaciones son la asistencia a todas las funciones de primera y segunda clase en los días festivos y demás que por dotación, voto o voluntad del cabildo se celebran con solemnidad. La de dar comunión a los fieles en todos los días del año, excepto en el carnaval y cumplimiento de iglesia que se hace por los capellanes de la cofradía del Santísimo Sacramento.

78 Maestro de ceremonias. Nombrado por el Duque. Asistir a las visperas y misa mayor en los días de primera o segunda clase y en cualesquiera otros que por dotación o a voluntad del Cabildo se celebran con igual solemnidad.

79 Al maestro de Capilla lo elige el cabildo, mediante oposición. El título se lo da el Duque. Obligaciones: regir la capilla de música, hacer las composiciones que se han de cantar, enseñar a los seises y debe asistir a cantar las vísperas y misas de primera y segunda clase.

$80 \mathrm{El}$ sochantre lo elige el cabildo por oposición. El título lo da el Duque. Obligaciones: asistir diariamente al coro, regir éste en el canto en todas las horas canónicas y enseñar el canto llano a los seises. Si el sochantre fuese músico tiene una parte en la capilla y por ella percibe anualmente 750 reales. Nota. Es corta la renta del sochantre atendido su mucho trabajo, la escasez de buenas voces para este destino y lo bien pagados que se hallan en otras iglesias, aún las de mediano mérito.

81 Al organista lo elgie el cabildo mediante oposición. El título lo da el Duque. Obligaciones: tocar el órgano o clave en todas las funciones eclesiásticas. Debe asistir a todos los entierros con los capellanes y con precisión y gratis a los de muy pobres.

82 El bajonista se provee por el Duque a propuesta del cabildo. Obligaciones: tocar el bajón (instrumento músico de viento construido de una pieza de madera como de $80 \mathrm{~cm}$. de largo, con 8 agujeros para los dedos y otro $u$ otros dos que se tapan con llaves; en su parte lateral superior se encaja un tudel de cobre de forma curva y en éste una pipa de cañas con la cual se hace sonar el instrumento, que tiene la extensión de bajo y sirve en orquesta para dar tono y acompañar a los salmistas en las funciones eclesiásticas). Debe enseñar a tocar este instrumento a cualquiera de los seises que to quieran aprender. 


\begin{tabular}{|l|r|}
\hline Sacristanes menores ${ }^{83}$ & 2.760 \\
\hline Seises (cada uno) ${ }^{84}$ & 100 \\
\hline Pertiguero 85 & 633 \\
\hline Candelario 86 & 1.114 \\
\hline Campanero 87 & 2.208 \\
\hline Ministral del 6rgano ${ }^{88}$ & 420 \\
\hline Custodio 89 & 160 \\
\hline
\end{tabular}

Se completó el estudio con las rentas de la fábrica de la Colegial, así como las del Patronato de Benito Carvajal, Cofradia de Ánimas y Cofradía del Santísimo Sacramento ${ }^{90}$. Las rentas de fábrica se administraba

83 Los dos sacristanes menores lo son por nombramiento del obispo. Obligaciones: cuidar de la iglesia, asistir a todas las misas cantadas y oficios divinos. Cada uno recibía 1.335 reales.

84 Los seises - cada uno de los niños del coro, seis por lo común, que vestidos lujosamente con traje antiguo de seda azul y blanca, bailan y cantan-son cuatro los que tiene esta iglesia para el servicio de coro. Los busca el maestro de capilla, dando parte al abad de los que entran de nuevo. Cantan los saimos y versículos, y cuando están adiestrados en el canto figurado desempeñan en la capilla de música el papel para el que son aptos, según sus voces. Nota. También es cortísima la asignación a los seises, o mozos de coro, y por esta causa no ha en la actualidad ninguno en esta iglesia.

85 Al pertiguero lo nombra el Duque. Obligaciones: asistir a misa mayor los domingos y dias festivos a las visperas de primera y segunda clase. El pertiguero es el ministro secular de las iglesias catedrales, que asiste acompañando a los que ofician en el altor, coro, púlpito y otros ministros, llevando en la mano una pértiga o vara larga guarnecida de plata.

86 Al candelario lo nombra el Duque. Obligaciones: aseo de la iglesia, cuidar del alumbrado de lámpara, poner los túmulos en los entierros y funerales, poner las colgaduras en la iglesia o capillas y asistir a los bautizos para preparar lo necesario para ellos.

87 Al campanero lo nombra el Duque. Obligaciones: tocar las campanas, abrir y cerrar las sepulturas para la sepeliación de cadáveres.

88 Lo nombra el cabildo y su poseedor. Obligación: levantar los fuelles del órgano siempre que éste se toque.

89 Este cargo de custodio estaba unido al antecedente y lo nombraba el Duque. Obligaciones: asistir a la iglesia los domingos y días de fiesta, y en cualquier otro que celebre con solemnidad y estar en ella durante los divinos oficios, cuidando que los concurrentes guarden compostura y decencia. Impedir la entrada de perros y otros animales en el templo y arrojar de él a los que se hayan introducido. Nota. Esta plaza hace años se halla vacante y sin que nadie la solicite o haya solicitado por dos motivos: el uno porque la última parte de su ejercicio le há adquirido cierto desprecio en el vulgo, y lo otro lo cortísimo de la renta.

90 El cabildo disfrutaba en el convento de San Benito de la regular observancia de San Francisco de esta villa, la mitad de las rentas del patronato que funtdó Benito Carvajal. Estas rentas 
por un mayordomo que nombraba el Duque de Medinaceli, teniendo asignado por ello 88 rs. anuales. Sus ingresos totales ascendían a 13.561 rs. y $20 \mathrm{mrs}$. La inversión que efectuaba era de 13.824 reales, de lo que resultaba un déficit de -262 rs. y $14 \mathrm{mrs}$, que unidos a otros 331 rs. y $2 \mathrm{mrs}$. de déficit en los réditos en el crédito público y en los ingresos de algunos tipos de misas suponían un descubierto de -593 rs. y 16 mrs.

Por no haberse ido reparando poco a poco el edificio de la Colegial fue preciso además gastar alrededor de 22.000 rs. con el fin de evitar su ruina. Dicha cantidad fue recaudada, por una parte, gracias a las donaciones -mediante limosnas- efectuadas por el vecindario. El obispo contribuyó también con 1.200 rs., el Duque con 1.300 rs. y la misma fábrica invirtió de sus fondos y de cantidades tomadas a préstamo un total de 4.000 rs. Precisaba además la fábrica de 3.600 rs. para el arreglo del órgano y la sustitución de misales muy deteriorados.

\section{ARREGLO PARROQUIAL PROVISIONAL DE 1836}

La Colegiata de Zafra fue envejeciendo en todos los sentidos. Quedó viejo el templo que lo cobijaba, por lo que había necesitado de una importante reparación que culminó en el año 1820. Envejeció la entidad colegial, con sus anacrónicos e inveterados pleitos y un afán de boato, que era más propio de siglos pasados, y muy especialmente, envejecían los canónigos que se congregaban desesperanzados, en torno a unas reliquias de rentas y dotaciones, incapaces de mantener a su costa, el número abultado de ministros del culto, que desde tiempos remotos había gozado. En febrero de 1832, sólo quedaban 5 prebendados, que decididos a poner fin a su problema, elevaron un informe al obispo de Badajoz con el siguiente contenido: se lamentaban del estado decadente de la iglesia, principalmente por el corto número de ministros y serviciarios y ser todos de edad avanzada y con los consiguientes achaques, no pudiendo celebrar con dignidad las cargas de las funciones del cabildo. Informaban que para conservar el rango de estos cultos, tenía que haber,

se administraban por un administrador nombrado por el cabildo a quien se le asignaba por su trabajo un $6 \%$ de lo cobrado. Rentas con destino al culto divino:

\begin{tabular}{|l|c|c|}
\hline Ingresos & $568 \mathrm{rs}$. & 17 \\
\hline Descuento e inversión & $198 \mathrm{rs}$. & $17 \mathrm{mr}$. \\
\hline Sobran & $460 \mathrm{rs}$. & \\
\hline
\end{tabular}


indispensablemente, 6 canónigos, 4 racioneros y 8 capellanes de coro, suplicando que se concedieran cuanto antes estas tomas de posesión y estando de acuerdo, en que deberian quedar suprimidas las tres dignidades y el cargo de abad mitrado. Alababan al Patrono, el Duque de Medinaceli, por su religiosidad e interés hacia la Colegiata, a la que seguía atendiendo, a pesar de la Real orden de la Cámara, que aún no se estaba aplicando y que determinaba el cese de su patronato, pero que quedó en suspensión a consecuencia del recurso alzado por el protector. Concluían su informe, pidiendo la reducción de prebendas, con la supresión antedicha, pero insistiendo en que se concediesen y confirmasen las colaciones de los que iban a seguir formando parte del reducido cabildo colegial hasta su muerte ${ }^{91}$.

En junio de 1836, la diócesis de Badajoz carecia de la presencia personal de su obispo D. Mateo Delgado Moreno. En ausencia de este prelado era gobernador eclesiástico de Badajoz D. Gabriel Rafael Blázquez Prieto que, en palabras de D. Manuel Ibarra, contador del Duque, fue siempre un rival fuerte de la Colegiata, firmó un documento el 11 de junio de ese año, que supuso el primer paso dado en firme para la supresión de la Colegiata. Según sus afirmaciones, el proceso instruido hacia el arreglo de la iglesia Colegial y parroquia de Zafra no estaba de acuerdo con la Real orden de 12 de junio de 1769 , que intentó soluciones más restrictivas, que las que ahora se pretendian, como era la supresión de canonjías y el cese de los patronatos de los duques, dos soluciones que se habían ido demorando por más de sesenta años, debido a los recursos alzados contra ella y que paralizaron su entrada en vigor.

D. Gabriel Rafael Blázquez Prieto, en el informe de 11 de junio de 1836, expuso que la Reina Gobernadora y su gobierno habían considerado de urgente necesidad la realización de un arreglo beneficial provisional de la Colegiata, para dar por zanjado el tema del derecho de patronato. En dicho documento se remontó a la firma del anterior plan beneficial y continó diciendo que en un posterior auto fechado el 12 de febrero de 1820 se emplazó y citó al arzobispo de Badajoz; al cabildo catedral, al Duque de Medinaceli, al cabildo eclesiástico de Zafra, al cura arcipreste de la Parra y a todos los interesados en este asunto. Sin embargo, ratificó que apenas se consiguió «que saliese a la causa los interesados y se formalizase el proceso con las correspondientes justificaciones en un término muy largo, aún de muchos años".

91 Croche de Acuña, Francisco, o. c. pp. 181-182. 
Por ello se procedió a la realización de un arreglo provisorio que se determinó de la siguiente forma: se puntualizó en principio que la iglesia de Santa María fue antiguamente la única parroquia de la villa de Zafra, y el Duque de Medinaceli y Feria y sus antecesores no tuvieron en ella más derecho que cualquier otro de sus feligreses, a pesar de la novedad causada por las bulas expedidas por Paulo V y Urbano VIII en 1609 y 1631 respectivamente. Lo que sí se consiguió con esto era satisfacer la vanidad de algunos devotos, aumentando la pompa eclesiástica, mientras, la instrucción y el servicio espiritual de los fieles no fue atendido con verdadera piedad. Como consecuencia de ello especificó que la iglesia de Santa María se restituiría plenamente a su antigua condición de parroquia, extinguiéndose absolutamente la titulación de iglesia Colegial y de todo lo anejo a ella, así como lo concerniente al patronato particular laical del Duque de Medinaceli. Por tanto las citadas bulas no tendrían valor ni efecto alguno en lo sucesivo. En dicha iglesia existiría un cabildo eclesiástico, compuesto por un abad -que sería el único cura propio de su feligresíay de otros 12 canónigos coadjutores, con residencia permanente en la propia parroquia y con todas las cargas y obligaciones señaladas a los curas priores y beneficiados coadjutores en los reglamentos impresos de varias parroquias de esta diócesis que años atrás se aprobaron y que se publicaron con Reales cédulas auxiliatorias para su ejecución. Además, el abad y los canónigos coadjutores usarían en el ejercicio de su ministerio, en lugar de capa de oro y sobrepellín con mangas, roquete y muceta negra como los curas priores de las parroquias de Olivenza.

La suma de las rentas pertenecientes al cabildo eclesiástico, con separación de las tocantes a la fábrica parroquial, se dividirían en 14 partes iguales; de las que una sería para cada uno de los 12 canónigos coadjutores y las dos restantes se adjudicará al abad, a quien se reservarín privativamente las utilidades del ejercicio de la cura de almas, suprimiéndose en la iglesia parroquial todo lo respectivo a la Colegial, como dignidades, racioneros, capellanes de coro, pertiguero, maestro de capilla, violinista, seises y demás, sin perjuicio alguno de que la parroquia fuera decentemente servida "con espiritual edificación de los feligreses".

Si el Duque de Medinaceli quisiera hacer algunas reclamaciones en razón de los bienes raíces donados a la iglesia Colegial de Zafra, no se seguirán como hasta ahora litigios costosos e interminables, sino que el Duque procedería demandando particularmente en la Audiencia Episcopal cualquier finca, presentando las escrituras públicas respectivas. EI propio cabildo eclesiástico de la parroquial informaría también sobre el 
particular, y visto lo expuesto por una y otra parte, se dictaría lo que pareciera conveniente. Pero no se procedería a su ejecución sin el visto bueno de la Secretaría del Estado del Despacho de Gracia y Justicia, a fin de que la Reina Gobernadora pudiera aprobar, enmendar o reprobar y dictar las leyes que considerase oportunas, para una justa y rápida finalización del proceso.

Desde luego se ofrecieron a la consideración de la Reina algunos puntos sobre los que en un futuro serian necesarias providencias, como por ejemplo, que alguno de los canónigos coadjutores por turno o de otra manera, residiera en el barrio del suprimido convento de la Lapa y en su iglesia celebrase misa, explicase el evangelio, enseñase mediante catequesis la doctrina cristiana y administrase los sacramentos de penitencia, eucaristía, viático y extremaución, y se practicase lo mismo en alguna otra de las iglesias de los conventos suprimidos y basílicas o ermitas de Zafra. Que en la parroquia hubiera algunas misas a hora fija en el día, en que el pueblo tenía obligación de oírla, junto con otras cosas que convendría ordenar, oyendo informativa y gubernativamente a eclesiásticos y seculares, por lo que sería muy conveniente llevar a cabo este arreglo provisional.

La abadia y las doce canonjías coadjutorales de la iglesia parroquial se proveerian previos edictos y concurso oposición mediante examen uad curam animarum". En las vacantes de los meses apostólicos y en los casos de las reservas según el Concordato de 1753, y las Reales órdenes posteriores, se remitirían al gobierno una terna con la lista de todos los opositores aprobados, para que la Reina nombrase y presentase al que fuera de su agrado para la abadía o canonjía coadjutoral vacante; y en los 4 meses ordinarios -marzo, junio, septiembre y diciembre- el obispo de esta diócesis elegiría entre los aprobados al que creyera más apto. El agraciado, en cualquier caso, recibiría la institución canónica y título colativo del prelado o de su vicario general o del capitular, mientras estuviese expedita la silla episcopal.

Finalmente se mandó hacer de este auto dos ejemplares. Los cuales se remitieron al Secretario de Estado y del Despacho de Gracia y Justicia, solicitando la confirmación real. Una vez verificada ésta, se llevaria a cabo el mencionado arreglo transitorio. Dicho auto se mandó también publicar en la Audiéncia Episcopal de Badajoz y en la iglesia parroquial de Zafra, en el tiempo del ofertorio de la misa conventual de un día festivo, para conocimiento de todos los interesados. 
De este modo, quedaron suprimidos el boato litúrgico colegial, las prestaciones de cargo por el Duque, la vida ociosa y regalada de los canónigos, que habían atendido sólo a las vacías solemnidades pasadas, y se prestó una mayor atención a las necesidades espirituales de la villa de Zafra. El provisor de la diócesis al efectuar este arreglo adujo las siguientes motivaciones personales: «no mirar a esta Iglesia dejándola en el estado agonizante en que muchos años ha, se halla, es un abandono repugnante al dictamen de mi razón, y a los religiosos sentimientos de mi corazón. Tratar de formar un proceso aun meramente instructivo con la observancia de los trámites legales es trabajar sin fruto alguno, a lo menos por un tiempo muy largo e indefinido. He reflexionado que el mejor remedio es arrancar la raíz del mal y que éste depende, de que un señor poderoso esclavizó en el siglo diez y siete a la libre antigua parroquia de la villa de Zafra, dándole la cualidad de Insigne Colegial y haciéndose su patrono, afin de que en ella haya habido superabundante número de Ministros Eclesiásticos y dependientes hoy miserablemente dotados y aplicados a ceremonias exterioridades del Divino Culto, más que a la predicación evangélica, enseñanza de la doctrina cristiana, administración de sacramentos y servicio espiritual de los fieles" 92. La resolución era irrevocable, "nada me parece más justo que restituir la Iglesia de Zafra a su verdadero estado antiguo de libre y pura parroquia y que se extinga el patronato del Duque de Medinaceli, lo que casi todo está resuelto por el Supremo Tribunal de la Real Cámara". Sin embargo, el derecho de recurso no estaba cerrado y asi lo podía hacer el cabildo y el Duque, aunque en opinión del provisor, iba a ser inuitil, porque la resolución anterior estaba ya prácticamente tomada y aprobada.

Un sacerdote, que se llamaba D. Pedro Delicado y era secretario del gobernador del obispado, fue quien logró conocer el contenido tajante del anterior auto del provisor de Badajoz, e inmediatamente, lo comunicó el 17 de junio de 1836 a D. Román Tomás Enriquez, procurador de la hacienda del Duque en la capital pacense. Con urgencia, éste escribió al administrador del Duque D. Manuel Ibarra, el 18 de junio de 1836, poniéndole en antecedentes de lo que el provisor intentaba hacer en Zafra. El contador del Duque también se puso en contacto con el cabildo, que ignoraba el contenido del auto. El cabildo entonces se puso en manos del Duque y le instó a que abogase en su causa, directamente ante la Reina. Los canónigos, que estaban viendo venir, sobre ellos, la decisiva resolución de su desaparición como entidad colegial, no dejaron ningún

92 lodem, p. 187. 
instrumento y recomendación particular que esgrimir para evitarlo. La comunicación oficial la recibió el cabildo en los último días de junio de 1836, acompañada de una copia del auto, era la siguiente: "Es tan deplorable el estado de esta iglesia, que no puedo desentenderme en desempeño de mi cargo, y en 12 del corriente mes he proveido un auto por el que si S.M. la Reyna Gobernadora se digna confirmarlo, esta Iglesia será restituida a su antiguo libre estado de pura parroquia».

Los pocos canónigos, convencidos del poder resolutorio del provisor, en su empeño de acabar con la Colegiata, pusieron en juego sus influencias para intentar detenerla. El más representativo de ellos se llamaba D. Francisco Álvarez Guerra, éste era hermano de D. Juan Álvarez Guerra, uno de los personajes nacidos en Zafra, que habia conseguido escalar puestos de importancia oficial en la Corte, hasta llegar a ser Director General de Correos y más tarde, Ministro de Fomento. El citado canónigo buscó la influencia y mediación del político familiar. Por otro lado la gestión más directa la hizo el propio Duque de Medinaceli ante la Reina, mediante una carta datada el 26 de julio de 1836, por la que se suplicaba que fuera denegada la aprobación del expresado auto gubernativo.

Sin embargo, al parecer este expediente tardaría aún años en ejecutarse. Se sabe que en el año 1846 estaban al frente de la parroquia nada más que dos capitulares, D. Francisco Martínez y D. Manuel Angel del Río, y un racionero. Pascual Madoz nos informa que en 1850 seguía sin resolverse. Las quejas continuas de sus beneficiados al gobernador eclesiástico del obispado, en el sentido de que no percibian sus remuneraciones, o que las recibían tardes y menguadas, son prueba de que las intenciones gubernativas de atender el culto y clero no tuvieron reflejo en la realidad 93 .

\section{CONCORDATO DE 1851 Y LA REORGANIZACIÓN DE LA COLEGIATA}

El Concordato firmado entre la Santa Sede y la reina Isabel II, en 1851, vino a España a dar oficialidad a una Iglesia, que se intentaba que saliera reorganizada y que, renunciando a privilegios y a sus ingentes propiedades materiales de fincas y edificios, pudiese implantarse en un

93 Diccionario histórico-geográfico de Extremadura, vol. V, p. 299. 
nuevo tipo de sociedad ${ }^{94}$. El Concordato se firmó el 16 de marzo de 1851, cuando acababa de subir a la jefatura del Gobierno el moderado Bravo Murillo, que representaba la extrema derecha del partido monárquico conservador. Al Concordato de 1851 puede considerarse que se llegó fatalmente ante la imposibilidad de conseguir una reconciliación total y sincera. Por ello el Concordato no puede considerarse una obra perfecta, si bien pudo acabar con casi 20 años de tensiones entre la Iglesia y el Estado en España. Desde su promulgación su ejecución fue muy lenta y compleja. El 21 de noviembre se ordenó el arreglo del personal de las catedrales y colegiatas y la organización de las parroquias.

Los artículos del Concordato relacionados directamente con la Colegiata de Zafra eran el 21, 22 y 23. En el vigésimo primero, salvo algunas excepciones, se especificaba que «Todas las colegiatas, cualquiera que sea su origen, antigüedad y fundación, quedarán reducidas, cuando las circunstancias locales no lo impidan, a iglesias parroquiales, con el número de beneficiados que, además del párroco, se contemplen necesarios tanto para el servicio parroquial como para el decoro del culto. (...) Las iglesias colegiatas serán siempre parroquiales, y se distinguirán con el nombre de parroquia mayor si en el pueblo hubiese otra u otras". En el siguiente artículo se determinó la composición de la nueva parroquia «El cabildo de las colegiatas se compondrá de un abad presidente, que tendrá aneja la cura de almas, sin más autoridad o jurisdicción que la directiva y económica de su iglesia y cabildo; de dos canónigos de oficio, con los títulos de magistral y doctoral y de ocho canónigos de gracia. Habrá además seis beneficiados o capellanes asistentes". En el 23 por su parte, se decía que se observarian puntualmente en todas sus partes, en lo que respecta a las iglesias colegiatas, las reglas establecidas en los artículos anteriores referentes a provisión de las prebendas y beneficios o capellanias de las iglesias catedrales como para el régimen de sus cabildos.

El 1 de diciembre de 1851, el obispo de Badajoz, D. Francisco Javier Rodríguez Obregón, le remitió al presidente del Cabildo de Zafra la carta real que hacia referencia al expresado Concordato. El 31 de diciembre de 1853, la Colegiata ya era una simple parroquia según se desprende de un

94 ARTOLA, Miguel, La burguesía revolucionaria, en Historia de España, Alfaguara V, Madrid 1983, p. 143. CÁRCEL ORTí, Vicente, El liberalismo en el poder (1833-1868), en Historia de la Iglesia en España, vol. V, Madrid, 1979, pp. 115-225, especialmente en pp. 154-158. También realiza un comentario del Concordato CUENCA TORIBIO, José Manuel, en Iglesia y burguesía en la España liberal, Madrid, 1979, pp. 128-132. 
documento de D. Miguel Calabia, gobernador y vicario general de la Diócesis de Badajoz, sede vacante, por fallecimiento de este último obispo, en el que se determinaron las obligaciones de los eclesiásticos adscritos a la restaurada parroquia Nuestra Señora de la Candelaria, así como los derechos y dotaciones que debian percibir.

\section{CONCLUSIONES}

Con la creación de la Colegiata y en razón a los muchos derechos y prerrogativas que la Bula Pontificia otorgó al abad sobre la numerosa clerecía de la Candelaria, se abrieron una serie de caminos posibles que podían conducir $-y$ de hecho condujeron- a múltiples desacuerdos. Por una parte estaba la oposición institucionada por parte del Patronato Real, que el Rey tenía sobre la parroquia de Zafra, añadiéndose a éste, la exención que le dispensaba a esta importante parcela de Zafra y su clero, que por este mismo documento se separaban de la jurisdicción del obispo de Badajoz. Como caso muy especial, en esta villa se crearon dos jurisdicciones distintas entre los clérigos, pues, mientras una parte de ministros y capellanes quedaron incorporados a la recién creada Colegiata y dependientes del abad en todo, otra no menos numerosa comunidad de clérigos siguieron teniendo como superior jerárquico al obispo pacense. Todos estos inconvenientes que comenzaron a vislumbrarse, ya desde sus inicios, fueron la base de los frecuentes pleitos, enemistades, problemas y escándalos, que azotaron a la Colegiata desde su institución.

Todos estos condicionamientos repercutieron negativamente en los objetivos piopuestos en los distintos planes beneficiales que en la Colegiata se llevaron a cabo. En principio el plan del obispo Pérez Minayo de 1770 no contó con la aprobación del fiscal general ni de la Cámara de Castilla, quedando en suspenso tras la muerte del prelado. A continuación el plan de Solís y Gragera de 1786 tampoco llegó a verificarse. El de 1796 siguió la misma línea al plantearse el litigio del derecho de patronato. Posteriormente Mateo Delgado Moreno llegó a la conclusión de que la casua de la suspensión de la colación de beneficios que padecía la Colegiata en los años iniciales de su episcopado se debía a la falta de dotación, por lo que consideró justo la elaboración de un nuevo reglamento para la iglesia Colegial. Éste fue mandado efectuarse por el provisor Blázquez Prieto en el año 1816. Sin embargo, la Colegiata siguió envejeciendo en todos los sentidos, como lo demostró por ejemplo, el hecho de que 
en febrero de 1832 sólo quedaban cinco prebendados. No fue hasta el 11 de junio de 1836 cuando el entonces gobernador eclesiástico de Badajoz, el mencionado Blázquez Prieto, firmó un documento que supuso el primer paso dado en firme para la supresión de la Colegiata mediante el arreglo provisional iniciado ese mismo año. Mediante éste quedaron suprimidos el boato litúrgico colegial, las prestaciones de cargo por el Duque, la vida ociosa y regalada de los canónigos, y se prestó una mayor atención a las necesidades espirituales de la villa de Zafra. La culminación de todo el proceso, por el que de nuevo la Colegiata volvió a la categoría de parroquia con la advocación de Nuestra Señora de la Candelaria, después de 242 años de existencia, fue refrendado por los artículos 21, 22 y 23 del Concordato de 1851. 